\section{Pacific Northwest}

National Laboratory

Operated by Battelle for the

U.S. Department of Energy

\title{
Precipitation of Aluminum Containing Species in Tank Wastes
}

\author{
S.V. Mattigod \\ K.E. Parker \\ D.T. Hobbs \\ D.E. McCready
}

April 2002

Prepared for the U.S. Department of Energy under Contract DE-AC06-76RL01830 


\title{
PNNL-13881
}

\section{DISCLAIMER}

This report was prepared as an account of work sponsored by an agency of the United States Government. Neither the United States Government nor any agency thereof, nor Battelle Memorial Institute, nor any of their employees, makes any warranty, express or implied, or assumes any legal liability or responsibility for the accuracy, completeness, or usefulness of any information, apparatus, product, or process disclosed, or represents that its use would not infringe privately owned rights. Reference herein to any specific commercial product, process, or service by trade name, trademark, manufacturer, or otherwise does not necessarily constitute or imply its endorsement, recommendation, or favoring by the United States Government or any agency thereof, or Battelle Memorial Institute. The views and opinions of authors expressed herein do not necessarily state or reflect those of the United States Government or any agency thereof.

\author{
PACIFIC NORTHWEST NATIONAL LABORATORY \\ operated by \\ BATTELLE \\ for the \\ UNITED STATES DEPARTMENT OF ENERGY \\ under Contract DE-AC06-76RL01830
}

This document was printed on recycled paper. 


\section{Precipitation of Aluminum Containing Species in Tank Wastes}
S. V. Mattigod
D. T. Hobbs
K. E. Parker
D. E. McCready

April 2002

Prepared for

the U.S. Department of Energy

under Contract DE-AC06-76RL01830

Pacific Northwest National Laboratory

Richland, Washington 99352 


\section{Summary}

Aluminisilicate deposit buildup experienced during the tank waste volume-reduction process at the Savannah River Site (SRS) required an evaporator to be shut down in October 1999. The Waste Processing Technology Section of Westinghouse Savannah River Company at SRS is now collaborating with a team from Pacific Northwest National Laboratory to verify the steady-state thermodynamic stability of aluminosilicate compounds under waste tank conditions in an attempt to eliminate the deposition and clogging problems.

Tests were conducted to 1) identify the insoluble aluminosilicate phase(s) and characterize the chemistry and microstructure of these phases, 2) study the kinetics of the phase formation and transformation of such aluminosilicate phases under hydrothermal conditions, and 3) verify the stability boundaries in the activity diagram of interest to the $2 \mathrm{H}$ Evaporator, namely the critical concentrations of silica required to form insoluble aluminosilicates.

The data we obtained from tests conducted at $40^{\circ} \mathrm{C}$ showed that formation and persistence of crystalline phases was dependent on the initial hydroxide concentrations. The formation and persistence of zeolite A occurred only at lower hydroxide concentrations, whereas increasing hydroxide concentrations appeared to promote the formation of sodalite and cancrinite. The results showed that although zeolite A forms during initial period of reaction, due to it's metastability, converts to more stable crystalline phases such as sodalite and cancrinite. We also observed that the rate of transformation of zeolite $\mathrm{A}$ increased with increasing hydroxide concentration. The data from tests conducted at $80^{\circ} \mathrm{C}$ revealed relatively rapid formation of sodalite and cancrinite. Although minor amounts of zeolite A were initially detected in some cases, the higher reaction temperatures seemed to promote very rapid transformation of this phase into more stable phases. Also, the higher temperature and hydroxide concentrations appeared to initiate kinetically fast crystallization of sodalite and cancrinite. More recent testing at SRS in support of the high-level waste evaporator plugging issue has shown similar trends in the formation of aluminosilicate phases. Comparison of our results with those reported above show very similar trends i.e. initial formation of an amorphous precipitates followed by a zeolite phase that transforms to sodalite which finally converts to cancrinite. Our results also show the expected trend of an increased rate of transformation of initial precipitates into denser scaleforming aluminosilicate phases (sodalite and cancrinite) at higher temperature. 


\section{Acknowledgments}

The authors wish to thank Dr. Jonathan Icenhower, Pacific Northwest National Laboratory, and Dr. Carol Jantzen of Westinghouse Savannah River Company for providing technical reviews, and Rosalind Schrempf, Pacific Northwest National Laboratory, for technical editing and editorial review. This work is supported by the U.S. Department of Energy's Environmental Management Science Program. 


\section{Contents}

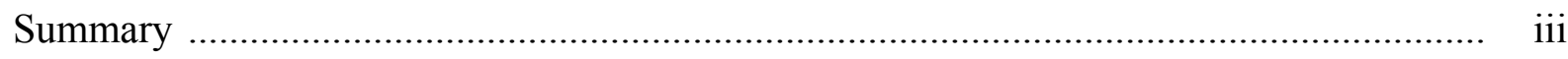

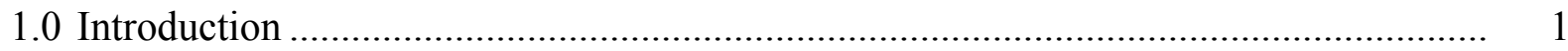

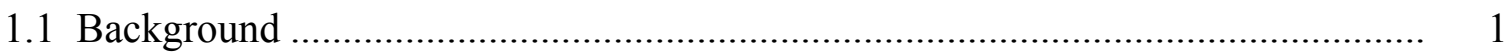

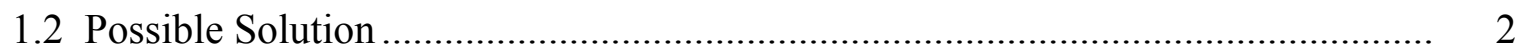

1.3 Literature Review on the Formation of Aluminosilicate (Zeolite) Compounds ..... 3

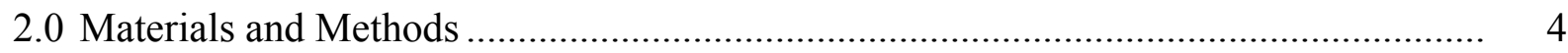

2.1 Selection of Hydroxide Concentrations ………….................................................

2.2 Selection of Salt Concentrations ………………….............................................

2.3 Reaction Temperature and Time ……………….............................................. 6

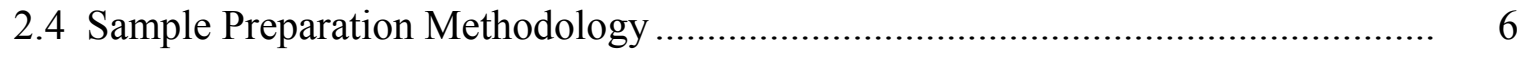

2.5 Solid and Liquid Sample Analysis ...................................................................... $\quad 7$

2.6 Turbidity and $\mathrm{pH}$ Measurements ....................................................................... 7

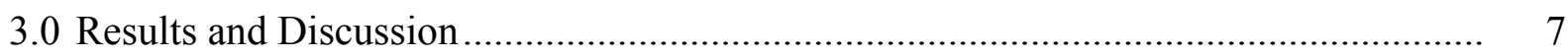

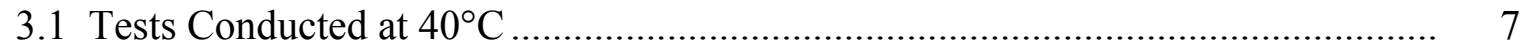

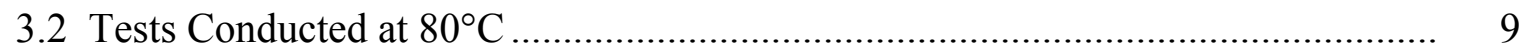

3.3 Turbidity and $\mathrm{pH}$ Measurements ................................................................... 14

3.4 Comparison of Results with Previous Testing …………................................... 16

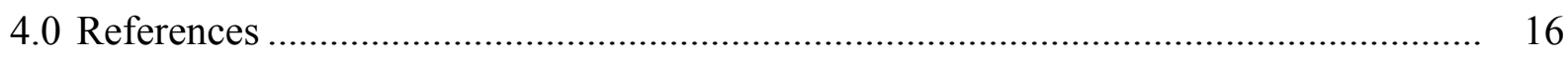

Appendix A. Semi Quantitative Method for Phase Determination from X-Ray Diffraction Data............................................................................ 19

Appendix B. Solution Composition and Solid Phase Data .............................................. 23 


\subsection{Introduction}

Aluminisilicate deposit buildup experienced during the tank waste volume-reduction process at the Savannah River Site (SRS) required an evaporator to be shut down in October 1999. The Waste Processing Technology Section (WPTS) of Westinghouse Savannah River Company at SRS is now collaborating with team members from Pacific Northwest National Laboratory (PNNL) to verify the steady-state thermodynamic stability of aluminosilicate compounds under waste tank conditions in an attempt to eliminate the deposition and clogging problems. This progress report describes the history of the problem, discusses relevant literature, and describes the test results obtained so far by the WPTS/PNNL team.

\subsection{Background}

High-level wastes (HLW) from fuel-reprocessing operations are evaporated at SRS to concentrate the waste to about 30 to $40 \%$ of its original volume before it is discharged into a holding tank. The $2 \mathrm{H}$-Evaporator system at SRS consists of a feed tank (Tank $43 \mathrm{H}$ ) that receives liquid wastes primarily from fuel-reprocessing operations and the Defense Waste Processing Facility (DWPF), the evaporator, and the concentrate receipt tank (currently Tank 38H). After evaporation, the concentrated wastes are transferred via a gravity drain line to the concentrate receipt tank. Frequently, the concentrated wastes from the concentrate receipt tank are transferred back into the evaporator feed tank for further volume evaporation.

For about four decades, SRS evaporators operated successfully with only occasional minor problems such as $\mathrm{NaNO}_{3}$ salt buildup and clogging of the drain lines from the evaporators. Because these deposits were water-soluble, the drain lines were unclogged easily by flushing with water. In 1997, the $2 \mathrm{H}$-Evaporator feed tank began receiving silicon-rich wastes from the DWPF recycle stream. The DWPF recycle waste stream is more dilute (contain less soluble salts) than fuel-reprocessing wastes, and thus requires a higher degree of concentration (typically $90 \%$ ) to reach the same salt concentrations as are found in the fuel-reprocessing wastes. The higher concentration requirement for DWPF waste and the existing operational problems resulted in significant increases in the residence time of these wastes in the $2 \mathrm{H}$ Evaporator.

Beginning in 1997, the silicon-rich DWPF waste stream was mixed with the aluminum-rich stream from the fuel-reprocessing operation in Tank $43 \mathrm{H}$, and this mixture was fed to the $2 \mathrm{H}$ Evaporator. Soon after, a sodium-aluminosilicate (zeolite-sodalite) deposit of limited solubility began to form in the evaporator ${ }^{1}$. During the August 1997 shutdown of this evaporator for cleaning, deposits of the zeolite and a sodium uranate phase were found in the gravity drain line

(GDL) $)^{2}$. The GDL was backflushed, and evaporation operations resumed until June 1998. From June 1998, operation of the $2 \mathrm{H}$ Evaporator became progressively more difficult due to the more frequent buildup of limited solubility aluminosilicate compounds and resulted in the shutdown of the evaporator in October 1999. An inspection revealed significant accumulations of deposits on most of the exposed surfaces of the evaporator. Analysis revealed that the deposits in the evaporator and the drain lines consisted mainly of a sodium aluminosilicate compound, sodalite $\left[\mathrm{Na}_{8} \mathrm{Al}_{6} \mathrm{Si}_{6} \mathrm{O}_{24}\left(\mathrm{NO}_{3}\right)_{2} \cdot 4 \mathrm{H}_{2} \mathrm{O}\right]$, and sodium diuranate $\left(\mathrm{Na}_{2} \mathrm{U}_{2} \mathrm{O}_{7}\right)^{3}$. Based on the extent of the lowsolubility deposits in the evaporator and in the drain lines, and the criticality concerns from the 
aggregated sodium-diuranate compound, it was decided to stop evaporator operations until a solution for this problem was found.

\subsection{Possible Solution}

One of the solutions to this clogging problem was the evolution of a method that uses nitric acid to dissolve the low-solubility compounds in the $2 \mathrm{H}$ Evaporator ${ }^{4}$. However, a complete amelioration of this problem requires a process control tool that can be used to predict critical mixing ratios for aluminum-rich and silicon-rich waste streams that will prevent the formation of the limited-solubility aluminisilicate compound (zeolite-sodalite) in the evaporator and the drain lines.

Activity or stability diagrams are used extensively to represent mineral-solution equilibria in natural systems ${ }^{5}$. These activity diagrams have been used to understand and predict the formation and stability of minerals under diverse geological environments that range from ambient earth-surface conditions to the hydrothermal $\left(\leq 300^{\circ} \mathrm{C}\right)$ ore-forming conditions in the earth's upper crust ${ }^{6}$. Recently, activity diagrams have been used to model the dissolution reactions of zeolites at ambient temperatures and compare the predicted stability of the zeolite phases with experimental data ${ }^{7}$. In another study, activity diagrams have been used to predict the dissolution of zeolites in the rock at the proposed HLW repository in Yucca Mountain, Nevada ${ }^{8}$. Therefore, activity (stability) diagrams can be used to model the formation of limited-solubility zeolites in the evaporator environment at SRS.

Because activity diagrams can be used as a steady-state thermodynamic tool to predict mineral equilibria (precipitation and dissolution), they can be used to predict the chemical conditions under which the sodium aluminosilicate and the sodium diuranate phases would form in the $2 \mathrm{H}-$ Evaporator at SRS. Formation of these limited-solubility compounds is observed to be relatively rapid because they form well within the residence times in the evaporator ${ }^{9}$. Therefore, the activity diagram scan be used to understand the feed chemistry versus the operating history of the SRS evaporators while calculations of supersaturation (expressed as saturation index, $Q / K$, where $\mathrm{Q}$ is ion activity product and $\mathrm{K}$ is the equilibrium constant for a specific solid phase) can be deployed as a process control tool to prevent problematic Al-Si waste stream ratios from feed Tank 43 from being fed to the $2 \mathrm{H}$-Evaporator. Also, activity diagrams for cleaning conditions can be constructed to understand the dissolution chemistry of the sodium aluminosilicate and sodium diuranate phases and to prevent the formation of other insoluble mineral deposits.

The main focus of this test plan was to obtain data on the characteristics of solid and liquid phases that would help verify the thermodynamic stability of aluminosilicate compounds under waste tank conditions as predicted by supersaturation calculations ${ }^{10}$. Such verification would enhance the utility and reliability of activity diagrams and supersaturation indices as predictive tools. 


\subsection{Literature Review on the Formation of Aluminosilicate (Zeolite) Compounds}

A brief review of literature that is pertinent to the aluminosilicate phases that have been observed to form in the $2 \mathrm{H}$-Evaporator at SRS indicates that zeolite $\mathrm{A}, \mathrm{Na}_{12} \mathrm{Al}_{12} \mathrm{Si}_{12} \mathrm{O}_{48} .27 \mathrm{H}_{2} \mathrm{O}$, is a phase related structurally to both sodalite and nosean ${ }^{11}$. The alumina:silica ratio of the basic cage structure is the same in both the zeolite $\mathrm{A}$ and sodalite. Basically, zeolite A consists of a doubleunit cell of sodalite without the $\mathrm{NaCl}, \mathrm{Na}_{2} \mathrm{SO}_{4}$, or $\mathrm{NaOH}$ groups attached. Recent work at the Argonne National Laboratory-West (ANL-W) on waste forms found that zeolite A formed as a precursor to the formation of sodalite, $\mathrm{Na}_{8} \mathrm{Al}_{6} \mathrm{Si}_{6} \mathrm{O}_{24}\left(\mathrm{Cl}_{2}\right)^{12}$. The zeolite A transformed to NaClcontaining sodalite under increased temperature and pressure along with a small amount of nepheline (NaAlSiO4).

From these data we can assume that it is very likely that in the $2 \mathrm{H}$-Evaporator, sodalite also forms from the zeolite A precursor. The formation of zeolite A is well studied and zeolite A is known to be kinetically a fast former. Well-crystallized zeolite A has been reported to form when a mixture of sodium-aluminate gel ( $87 \mathrm{wt} \% \mathrm{NaAlO}_{2}$ and $13 \mathrm{wt} \% \mathrm{NaOH}$ commercially available as Alfloc) and $1 \mathrm{M}$ colloidal silica sol (particles of 250A) has been reacted at temperatures between 85 and $110^{\circ} \mathrm{C}$ and at $\mathrm{pH}$ values $\geq 10$ for 2 or 3 hours. This research also reported slower crystallization with an increase in the silica content of the gel, and faster crystallization in the presence of excess $\mathrm{NaOH}^{11,13}$.

Studies by Gasterger et al. ${ }^{14}$ on spent pulping liquor evaporators, indicated that a mixture of sodalite and hydroxysodalite $\left[\mathrm{Na}_{8} \mathrm{Al}_{6} \mathrm{Si}_{6} \mathrm{O}_{24} \mathrm{Cl}_{2}\right.$ and $\left.\mathrm{Na}_{8} \mathrm{Al}_{6} \mathrm{Si}_{6} \mathrm{O}_{24}(\mathrm{OH})_{2}\right]$ precipitated at $95^{\circ} \mathrm{C}$ in the $\mathrm{Al} / \mathrm{Si}$ range between 0.076 and 3 in which $\mathrm{Al}(\mathrm{OH})_{4}{ }^{-}$and $\mathrm{HSiO}_{4}{ }^{3-}$ were the predominant aqueous species. These aqueous alkaline solutions had ionic strengths between 1.0 and 4.0 $\mathrm{mol} / \mathrm{kg}$ with the corresponding $\mathrm{OH}^{-}$concentrations of $\leq 0.09$ and $\leq 3.8 \mathrm{~mol} / \mathrm{L}$, respectively. He also observed that a sodium-aluminosilicate (NAS) gel was a precursor phase leading to the formation of zeolite A. Similarly, Ejaz et al. ${ }^{15}$ reported the initial formation of a metastable aluminosilicate precursor phase of higher solubility that with time alters to less soluble crystalline zeolite A. Based on an extensive literature review, Barnes et al. ${ }^{16}$ reported that reactions occurring in Bayer liquor at temperatures below $80^{\circ} \mathrm{C}$ initially form a metastable amorphous phase that subsequently crystallizes into zeolite A.

Zeolite A $\left(\mathrm{Na}_{12} \mathrm{Al}_{12} \mathrm{Si}_{12} \mathrm{O}_{48} \cdot 27 \mathrm{H}_{2} \mathrm{O}\right)$ has also been found to form in the SRS M-Area waste $\operatorname{tanks}^{17}$. Zeolite was found to form preferentially in tanks under high $\mathrm{pH}$ (12-12.8) conditions when solid $\mathrm{Al}(\mathrm{OH})_{3}$ was present. Experiments were performed to determine how zeolite A got into the tanks because no zeolite had been used in any M-Area process. These experiments demonstrated that a zeolite phase identified as sodalite $\left[\mathrm{Na}_{8} \mathrm{Al}_{6} \mathrm{Si}_{6} \mathrm{O}_{24}(\mathrm{Cl})_{2}\right]$ could form rapidly (within 29 hours) at room temperature from the interaction of high surface area aluminosilicates (perflo and diatomaceous earth) in the tank with a solution of $6 \mathrm{M} \mathrm{NaOH}$ solution ${ }^{17}$.

The objective of the tasks were to

1. Identify the insoluble aluminosilicate phase(s) and characterize the chemistry and microstructure of these phases. 
2. Study the kinetics of the phase formation and transformation of such aluminosilicate phases under hydrothermal conditions.

3. Verify the stability boundaries in the activity diagram of interest to the $2 \mathrm{H}$ Evaporator, namely the critical concentrations of silica required to form insoluble aluminosilicates.

This progress report includes some of the data from Phase I experiments. Results from the $40^{\circ} \mathrm{C}$ and $80^{\circ} \mathrm{C}$ tests, which included phase characterization and solution data, are part of this report. Other characterization data based on NMR and SEM/EDS analysis will be included in the next progress report.

\subsection{Materials and Methods}

A test matrix was designed to cover a range of hydroxide and salt concentrations and the reaction temperature and time encountered in evaporator operation. The basis for the test matrix is described below.

\subsection{Selection of Hydroxide Concentrations}

Three different regions are revealed in the activity diagrams on the vertical axis $\left[\mathrm{Al}(\mathrm{OH})_{4}{ }_{4}^{-} \mathrm{H}^{+}\right.$ ratio]: a soluble aluminum hydroxide region at low ratio, a gibbsite region at intermediate ratio, and a soluble aluminate region at high ratio. What solid phases will be formed depends on the $\mathrm{Al}(\mathrm{OH})_{4}{ }_{4}^{-} \mathrm{H}^{+}$ratios. Careful analysis of the activity diagrams and comparison with existing solubility diagrams in the aluminum hydroxide literature suggest that the activity diagrams depend on the dissolution behavior of aluminum hydroxide. At a low $\mathrm{pH}(\mathrm{pH}<5)$, aluminum hydroxide is soluble and exists as various hydrolyzed cations with a composition $\mathrm{Al}_{\mathrm{x}}(\mathrm{OH})_{\mathrm{y}}{ }^{(3 \mathrm{x}-\mathrm{y})+}$. Although the activity diagrams express the aluminum activities as $\mathrm{Al}(\mathrm{OH})_{4}{ }^{-}$, it is recognized that other cations also exist in the different $\mathrm{pH}$ regimes. At an intermediate $\mathrm{pH}(\mathrm{pH} 5-10)$, aluminum hydroxide is insoluble and exists mostly as gibbsite. At a high $\mathrm{pH}(\mathrm{pH}>10)$, dissolved aluminum exists as aluminate ion, $\mathrm{Al}(\mathrm{OH})_{4}^{-}$. Activity calculations account for all the species using appropriate activity coefficients and mass balance equations.

For waste storage and evaporation, the $\mathrm{pH}$ of the waste solutions would not be expected to fall below a $\mathrm{pH}$ of 10 . In Tank $43 \mathrm{H}$, the $\mathrm{pH}$ of the supernatant liquid is typically very high because the free hydroxide concentration ranges from 1 to $6 \mathrm{M}$. Thus, initial testing conditions were focused on values above a $\mathrm{pH}$ of 10 and below a free-hydroxide concentration of $6.0 \mathrm{M}$.

\subsection{Selection of Salt Concentrations}

The concentrations of the starting salts were based on the averaged results reported from Tanks $38 \mathrm{H}$ and $43 \mathrm{H}$ (Table 1). Some of the most important salts include $\mathrm{NaAlO}_{2}, \mathrm{NaNO}_{3}$, with varying silica and hydroxide concentrations. Other salts, including carbonates and sulfates, have low concentrations and will not be considered in the initial testing. 
Table 1. Measured Salt Concentration in Tanks 38H and 43H

\begin{tabular}{|c|c|c|c|c|c|}
\hline \multicolumn{7}{|c|}{ Tank 38H Historical Data (moles/L) } \\
\hline Date & $\mathbf{O H}^{-}$ & $\mathbf{S i}$ & $\mathbf{A l}$ & $\mathbf{N O}_{\mathbf{3}}{ }^{-}$ & $\mathbf{N a}$ \\
\hline $11 / 92$ & 9.6 & 0.007 & 0.53 & 2.63 & 13.88 \\
\hline $11 / 97$ & 5.0 & 0.006 & 0.22 & 2.69 & 8.44 \\
\hline $2 / 98$ & 5.9 & 0.007 & 0.36 & 3.62 & 10.16 \\
\hline $5 / 98$ & 4.2 & 0.003 & 0.03 & 2.40 & 7.32 \\
\hline $8 / 98$ & 6.2 & 0.003 & 0.15 & 3.60 & 10.56 \\
\hline $11 / 98$ & 4.4 & 0.005 & 0.01 & 2.42 & 7.05 \\
\hline $3 / 99$ & 6.2 & 0.018 & 0.12 & 4.47 & 11.40 \\
\hline $8 / 99$ & 6.0 & 0.010 & 0.26 & 4.22 & 11.03 \\
\hline $11 / 99$ & 1.5 & 0.002 & 0.28 & 1.40 & 4.11 \\
\hline $12 / 99$ & 2.5 & 0.002 & 0.28 & 2.62 & 6.38 \\
\hline Average & 4.76 & 0.006 & 0.19 & 3.05 & 8.50 \\
\hline \multicolumn{7}{|c|}{ Tank 43H Historical Data (moles/L) } \\
\hline $11 / 92$ & 10.4 & 0.006 & 0.46 & 3.61 & 15.75 \\
\hline $11 / 97$ & 3.4 & 0.006 & 0.06 & 1.63 & 5.58 \\
\hline $2 / 98$ & 2.8 & 0.004 & 0.18 & 1.70 & 4.90 \\
\hline $5 / 98$ & 3.2 & 0.003 & 0.07 & 1.73 & 5.33 \\
\hline $8 / 98$ & 2.9 & 0.004 & 0.06 & 1.61 & 4.77 \\
\hline $11 / 98$ & 4.8 & 0.005 & 0.01 & 2.06 & 7.10 \\
\hline $3 / 99$ & 4.0 & 0.001 & 0.01 & 2.79 & 7.11 \\
\hline $6 / 99$ & 2.9 & 0.005 & 0.20 & 2.08 & 5.30 \\
\hline $8 / 99$ & 4.2 & 0.021 & 0.14 & 2.97 & 8.09 \\
\hline $11 / 99$ & 3.6 & 0.004 & 0.20 & 3.48 & 6.50 \\
\hline Average & 3.5 & 0.006 & 0.10 & 2.23 & 6.08 \\
\hline
\end{tabular}

The initial experimental strategy, as outlined in the test plan, was to vary the hydroxide and silica concentrations for a fixed aluminum concentration. Thus, for a given fixed aluminum concentration, hydroxide concentrations (e.g., from $0.01 \mathrm{M}$ to $4.5 \mathrm{M}$ ) and silica concentrations (e.g., from $2.2 \mathrm{E}-05 \mathrm{M}$ to $2.4 \mathrm{E}-02 \mathrm{M}$ ) will be varied so that test conditions will span both sides of the predicted boundary between aluminum hydroxide and aluminosilicate phases. However, consultations between the WPTS/PNNL team members led to a decision to initially focus on tests involving aluminum concentrations of $\sim 0.2$ and $\sim 0.5 \mathrm{M}$, the hydroxide concentrations of $\sim 0.1, \sim 1$, and $\sim 4.5 \mathrm{M}$, at a fixed silica concentrations of $0.01 \mathrm{M}$ in a $\sim 3 \mathrm{M}$ sodium nitrate matrix. The test matrix solution compositions used in these sets of experiments are listed in Table 2. These compositions were selected to represent a range of solution conditions that were encountered during the evaporator operations (Table 1). The average solution compositions from the evaporators are closely represented by solution 5 in the test matrix (Table 2). Future tests will include higher silica concentrations as needed to provide data to support evaporator operations. 
Table 2. Solution Compositions Used in the Test Matrix

\begin{tabular}{|c|c|c|c|c|c|}
\hline $\begin{array}{c}\text { Solution } \\
\text { No. }\end{array}$ & $\begin{array}{l}\mathrm{OH} \\
(\mathrm{M})\end{array}$ & $\begin{array}{c}\mathbf{S i} \\
(\mathbf{M})\end{array}$ & $\begin{array}{c}\mathrm{Al} \\
(\mathrm{M})\end{array}$ & $\begin{array}{c}\mathrm{NO}_{3} \\
(\mathrm{M})\end{array}$ & $\begin{array}{l}\mathrm{Na} \\
(\mathrm{M})\end{array}$ \\
\hline 1 & 0.1 & 0.01 & 0.2 & 3 & 3.31 \\
\hline 2 & 0.1 & 0.01 & 0.5 & 3 & 3.61 \\
\hline 3 & 1.0 & 0.01 & 0.2 & 3 & 4.21 \\
\hline 4 & 1.0 & 0.01 & 0.5 & 3 & 4.51 \\
\hline 5 & 4.5 & 0.01 & 0.2 & 3 & 7.71 \\
\hline 6 & 4.5 & 0.01 & 0.5 & 3 & 8.01 \\
\hline
\end{tabular}

\subsection{Reaction Temperature and Time}

Four reaction temperatures were studied: $40^{\circ} \mathrm{C}, 80^{\circ} \mathrm{C}, 120^{\circ} \mathrm{C}$, and $175^{\circ} \mathrm{C}$. The results from testing at these temperatures will cover the range of temperatures encountered during the storage and evaporation of waste solutions. Phase I testing consisted of experiments conducted at $40^{\circ} \mathrm{C}$, and $80^{\circ} \mathrm{C}$, and Phase II tests to be conducted will include the experiments at $120^{\circ} \mathrm{C}$ and $175^{\circ} \mathrm{C}$. This report includes results of Phase I tests. The reactions were carried out over varying periods of time to study the initial precipitation and the crystallization (transformation) process. At 120 ${ }^{\circ} \mathrm{C}$ and $175^{\circ} \mathrm{C}$, sampling will include times representative of residence times in the evaporator (e.g., from 4 to 8 hours).

\subsection{Sample Preparation Methodology}

For the Phase I study the method for preparing $0.2-0.5 \mathrm{M} \mathrm{Al}, 0.01 \mathrm{M} \mathrm{Si}, 0.1-4.5 \mathrm{M} \mathrm{NaOH}$, and $3 \mathrm{M} \mathrm{NaNO}_{3}$ solutions was as follows:

1. Required quantity of $\mathrm{NaOH}$ was dissolved in deionized distilled $\mathrm{H}_{2} \mathrm{O}$ in a polypropylene beaker.

2. Appropriate quantity of sodium nitrate was added to the $\mathrm{NaOH}$ solution and stirred.

3. To the solution prepared in Step 2, weighed quantity of $\mathrm{NaAlO}_{2}$ and a sufficient volume of deionized distilled water was added to bring the total solution to the required concentration and stirred for 30 minutes. These steps provided $0.5 \mathrm{~L}$ to $6 \mathrm{~L}$ solution containing $0.2 \mathrm{M} \mathrm{Al}, 4.5 \mathrm{M} \mathrm{NaOH}$, and $3 \mathrm{M} \mathrm{NaNO}_{3}$.)

4. Next, an appropriate amount of sodium silicate (containing $14 \mathrm{wt} \%$ silica, $\mathrm{SiO}_{2}$ ) was added to the solution produced in Step 3. (The addition of sodium silicate was designed to produce solutions that contain $10^{-2} \mathrm{M}$ silica concentrations.) The test mixtures were stirred and kept in an oven set to the appropriate temperature $\left(40{ }^{\circ} \mathrm{C}\right.$ and $\left.80{ }^{\circ} \mathrm{C}\right)$.

5. At appropriate times, samples were removed from the oven for analysis.

6. Samples were centrifuged at $3000 \mathrm{rpm}$ for 5 minutes to separate the solid and liquid phases. An aliquot of the liquid phase was filtered and analyzed for dissolved constituents. The solid phase was washed free of salts using deionized distilled water, airdried and analyzed by X-ray powder diffraction (XRD).

These samples compositions are listed in Tables 2. 


\subsection{Solid and Liquid Sample Analysis}

The solid samples were analyzed by XRD to identify the crystalline phases containing aluminum and silicon. The XRD apparatus was a Philips X'Pert MPD system (Model PW3040/00) with a $\mathrm{Cu}$ X-ray source operated at $45 \mathrm{kV}, 45 \mathrm{~mA}(1.8 \mathrm{~kW})$. The scan range was $5^{\circ}-75^{\circ}$ and the typical scan rate was $\sim 2 \%$ min. The XRD data were analyzed using the program JADE (V5.0, V6.0, and V6.1, Materials Data Inc., Livermore, CA) and reference data from the Powder Diffraction File Database (PDF-2, International Centre for Diffraction Data, Newtown Square, PA). Details of semiquantitative analyses of the solid phases are provided in Appendix A. The semiquantitive $\mathrm{XRD}$ analyses were all unstandardized, therefore the mass estimates are less precise than values obtained from quantitative analyses conducted with appropriate standards. Therefore, the numerical values in tables and graphs represent trends in phase transformation. Details of semiquantitative analyses of the solid phases are provided in Appendix A.

The solutions were analyzed for dissolved aluminum and silicon using inductively-coupled plasma (ICP) spectrometry. Total elemental analysis was performed on portions of the solids.

\subsection{Turbidity and $\mathrm{pH}$ Measurements}

Although the Test Plan did not include any additional measurements, during Phase I experiments a separate set of Solutions 1 and 2 was prepared to assess any changes in $\mathrm{pH}$ as a function of reaction progress at $80^{\circ} \mathrm{C}$. Similarly, any changes in turbidity that reflected homogeneous nucleation at $80^{\circ} \mathrm{C}$ in Solutions 5 and 6 without added silica were monitored.

\subsection{Results and Discussion}

\subsection{Tests Conducted at $40^{\circ} \mathrm{C}$}

The results of the $40^{\circ} \mathrm{C}$ tests are included in Appendix B. The crystalline solid phases identified in these experiments were zeolite A, sodalite, and cancrinite (Figure $1 \mathrm{a}-\mathrm{f}$ ). An amorphous component was present in each of the tests. The relative proportions of these solid phases changed as a function of reaction time. For instance, in Solution 1 at 14 days, the amorphous component was a major phase ( $80 \%)$ with zeolite A constituting about $20 \%$ of the mass (Figure 1a). Solids samples obtained at the end of 30, 45, and 60 days, however, showed zeolite A to be the dominant phase $(\sim 65 \%)$. The relative proportion of zeolite $\mathrm{A}$ and the amorphous phase appeared to be relatively constant after 30 days of reaction, suggesting an apparent steady-state equilibrum. In experiments involving Solution 2, zeolite A appeared to be the dominant phase $(\sim 60-65 \%)$ at all sampling times, indicating that formation of zeolite A proceeded more rapidly with initially higher soluble Al concentration (Figure $1 \mathrm{~b}$ ). Again, solids sampled obtained at 45 and 60 days suggested the existence of an apparent steady-state equilibrium.

Test Solutions 3 and 4 contained higher sodium hydroxide concentrations ( $1 \mathrm{M})$. Solid samples obtained from these solutions after 14 days of reaction revealed that the precipitates contained mainly zeolite A $(\sim 30-\sim 50 \%)$ and amorphous material $(\sim 45 \%)$ with small amounts of nitrated sodalite and cancrinite (Figure $1 \mathrm{c}, \mathrm{d}$ ). In both cases, longer reaction times did not seem to 
change the mass of amorphous material; however, there were decreasing quantities of zeolite A with a concomitant increase in amounts of sodalite and cancrinite. These data suggested that zeolite $\mathrm{A}$ is metastable and that sodalite and cancrinite had formed as alteration products.

Samples obtained at the end of 30, 45, and 60 days indicated that alteration reactions were still
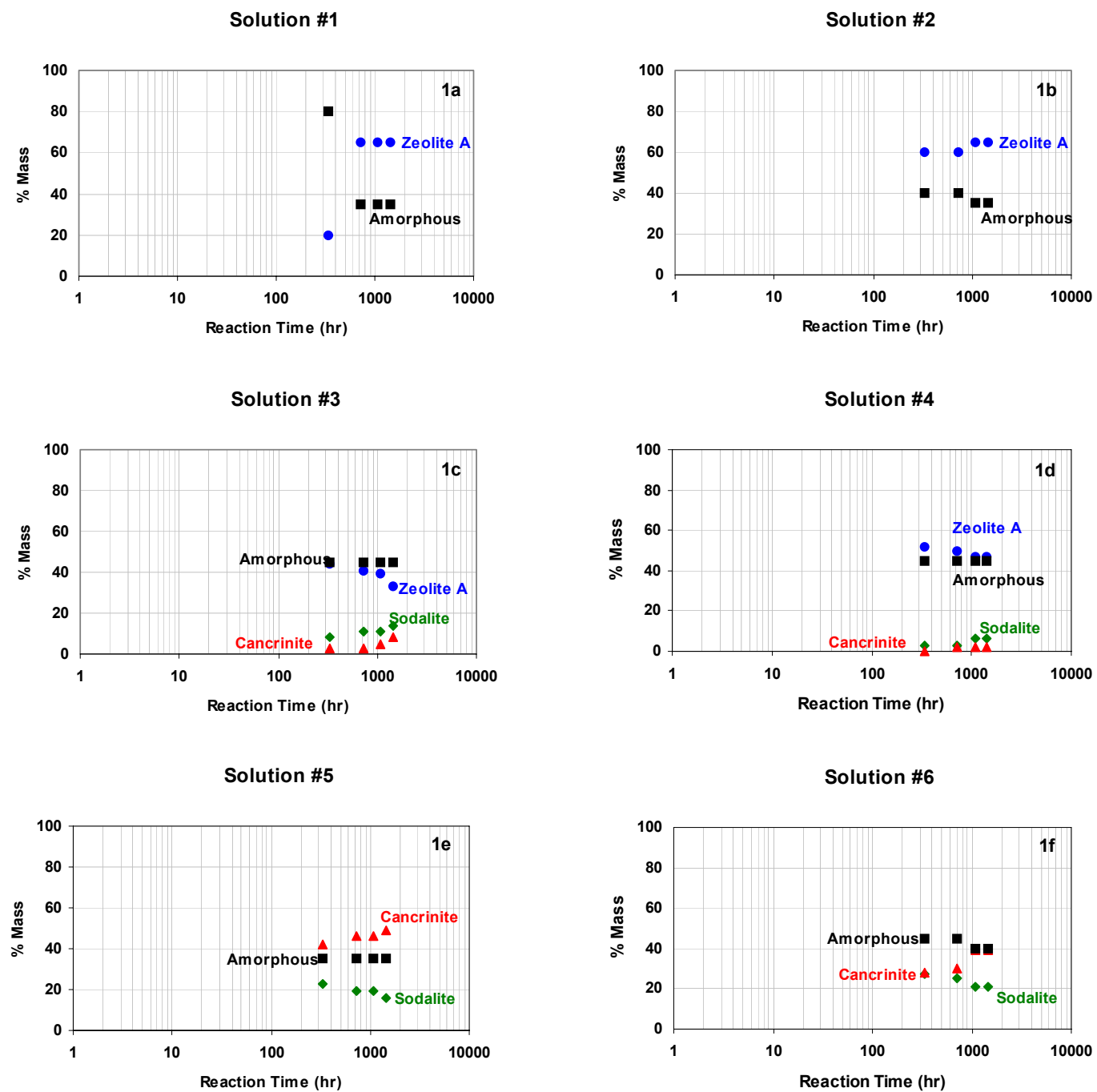

Figure 1. Solid Phases Identified as a Function of Reaction Time $\left(40^{\circ} \mathrm{C}\right)$

occurring as indicated by the declining mass of zeolite A and increasing quantities of sodalite and cancrinite. Higher sodium hydroxide concentrations in Solutions 5 and 6 appeared to promote more rapid formation of sodalite and cancrinite (Figure 1e,f). During all sampling periods, the mass of amorphous material appeared to remain constant $(\sim 35-45 \%)$ with the remaining mass consisting of sodalite and cancrinite. Additionally, the data indicated that the mass of sodalite was declining with time and with a concomitant increase in the mass of cancrinite. It appeared that under these experimental conditions, sodalite was metastable and 
was altering to a more stable phase, namely, cancrinite. The data indicated that phase transformation was continuing even after 60-day reaction period.

The solid phases obtained from all solutions at the end of the 60-day reaction period are listed in Table 3. The data showed that formation and persistence of crystalline phases was dependent on the initial hydroxide concentrations. For instance, the formation and persistence of zeolite A occurred only at lower hydroxide concentrations, whereas increasing hydroxide concentrations appeared to promote the formation of sodalite and cancrinite. The data also showed that although zeolite A forms initially, it is a metastable phase that converts to more stable crystalline materials such as sodalite and cancrinite The rate of transformation of zeolite A appeared to increase with increasing hydroxide concentration.

Table 3. Phases Identified at the End of 60-Day Reaction at $40^{\circ} \mathrm{C}$

\begin{tabular}{|l|l|l|l|l|l|}
\hline \multirow{2}{*}{$\begin{array}{l}\text { Solution } \\
\text { No. }\end{array}$} & \multicolumn{5}{|c|}{ Mass (wt \%) } \\
\cline { 2 - 6 } & $100-80$ & $80-60$ & \multicolumn{1}{|c|}{$60-40$} & \multicolumn{1}{|c|}{$40-20$} & $20-<10$ \\
\hline 2 & & Zeolite A & & Amorphous & \\
\hline 3 & & Zeolite A & & Amorphous & \\
\hline 4 & & Amorphous & Zeolite A & $\begin{array}{l}\text { Sodalite, } \\
\text { Cancrinite }\end{array}$ \\
\hline 5 & & & $\begin{array}{l}\text { Zeolite A, } \\
\text { Amorphous }\end{array}$ & & $\begin{array}{l}\text { Sodalite, } \\
\text { Cancrinite }\end{array}$ \\
\hline 6 & & Cancrinite & Amorphous & Sodalite \\
\hline $\begin{array}{l}\text { Sodalite: } \mathrm{Na}_{8}\left[\mathrm{AlSiO}_{4}\right]_{6}\left(\mathrm{NO}_{3}\right)_{2}(\mathrm{PDF} \# 50-0248) \\
\text { Cancrinite: } \mathrm{Na}_{8}\left[\mathrm{AlSiO}_{4}\right]_{6}\left(\mathrm{NO}_{3}\right)_{2} \cdot 4 \mathrm{H}_{2} \mathrm{O}(\mathrm{PDF} 338-0513) \\
\text { Zeolite A: } \mathrm{Na}_{96} \mathrm{Al}_{96} \mathrm{Si}_{96} \mathrm{O}_{384}(\mathrm{PDF} 39-0223) \\
\text { Cancrinite }\end{array}$ & Sodalite \\
\hline \multicolumn{5}{|l|}{} \\
\hline
\end{tabular}

Concentrations of dissolved species measured at each sampling time indicated that in all solutions, substantial fractions of Si $(80-100 \%)$ originally present in solution had precipitated (Figures 2). In all solutions, Si removal increased as a function of time and did not reach the maximum until reactions had proceeded for at least 45 days. Also, the extent of Si precipitation in these solutions appeared to be a function of hydroxide concentrations. For instance, at the end of 60 days, almost complete removal $(\sim 100 \%)$ of Si was observed in Solutions 1 and 2, whereas in Solution 5 and 6, only $\sim 80-85 \%$ of dissolved Si had precipitated. Comparatively, only minor fractions of soluble $\mathrm{Al}$ ( $\sim 5$ to $10 \%$ ) initially present had precipitated. The fractions of $\mathrm{Al}$ precipitated from these solutions could not be reliably assessed from solution analysis data because of the small amounts of $\mathrm{Al}$ precipitation and the high initial $\mathrm{Al}$ concentrations. 


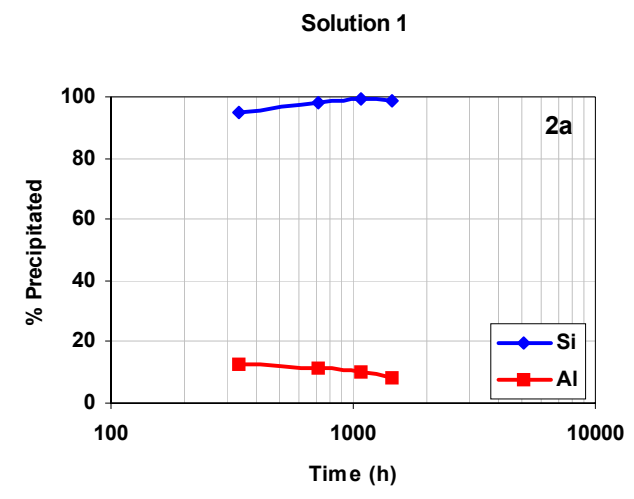

Solution 3

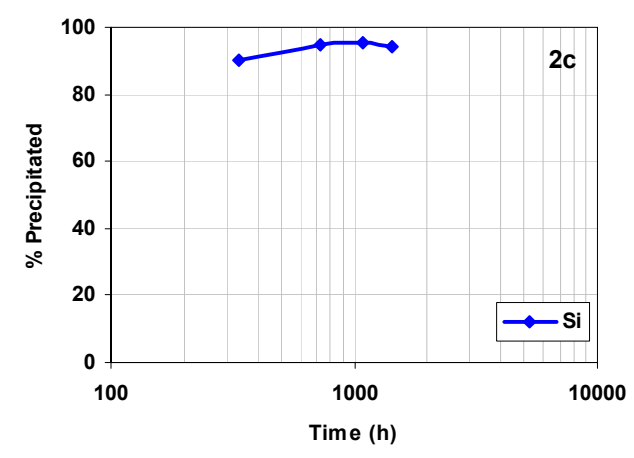

Solution 5

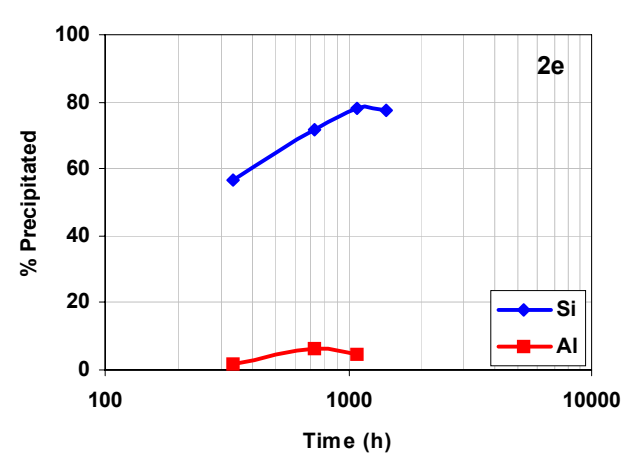

Solution 2

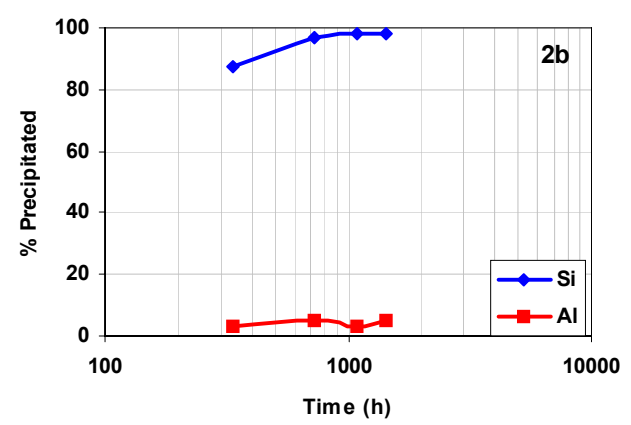

Solution 4

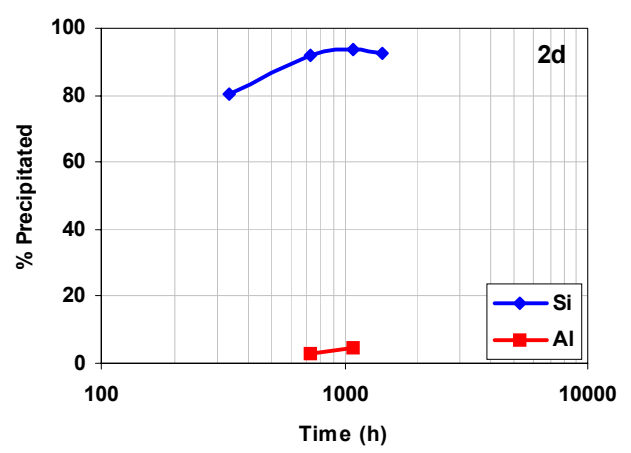

Solution 6

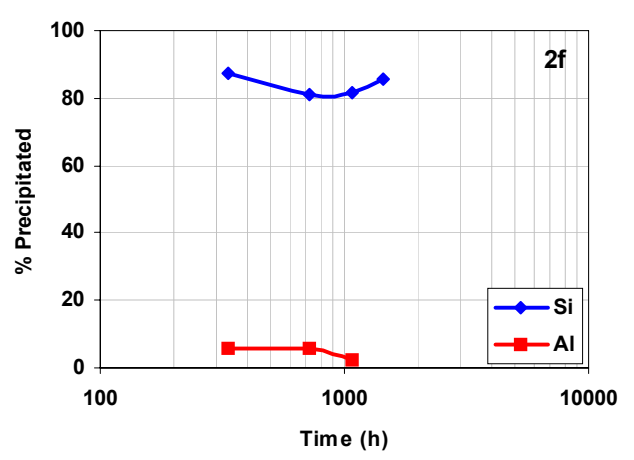

Figure 2. Fractions of $\mathrm{Al}$ and Si Precipitating Out of Solution $\left(40^{\circ} \mathrm{C}\right)$

\subsection{Tests Conducted at $80^{\circ} \mathrm{C}$}

The results of these tests are included in Appendix B. Solid phase analyses indicated that upon mixing, an amorphous phase formed in Solutions 1 through 4 (Figures 3a- d). In Solutions 5 and 6 , initial amounts of the precipitates were mainly colloidal in nature, and therefore, could not be recovered in sufficient quantities for characterization. The precipitate from Solution 1 (Figures 3a) remained amorphous for about 8 hours before formation of crystalline phases were detected. These crystalline phases consisted mainly of sodalite with trace amount of zeolite A. With 
increasing reaction time, the quantities of sodalite increased with a concomitant decrease in the quantity of amorphous material. After 24 hours, in addition to the amorphous phase and sodalite, trace quantities of cancrinite were detected. Continued sampling of precipitates indicated continual decrease in quantities of amorphous material coupled with increasing quantities of crystalline phases, namely sodalite and cancrinite. Apparently, equilibrium existed in this system because after 14 days of reaction there were no substantial changes in relative quantities of these phases.

The initial precipitate obtained from Solution 2 was also amorphous for the initial 4-hour reaction period (Figure $3 b$ ). Samples obtained after 8 hours showed that about a third of the solid mass consisted of sodalite with a trace of zeolite A. Solid phases at the end of 1 and 2 days contained decreasing amounts of amorphous materials with increasing quantities of sodalite and minor amounts of cancrinite. Samples obtained after 7 days showed that gibbsite constituted a
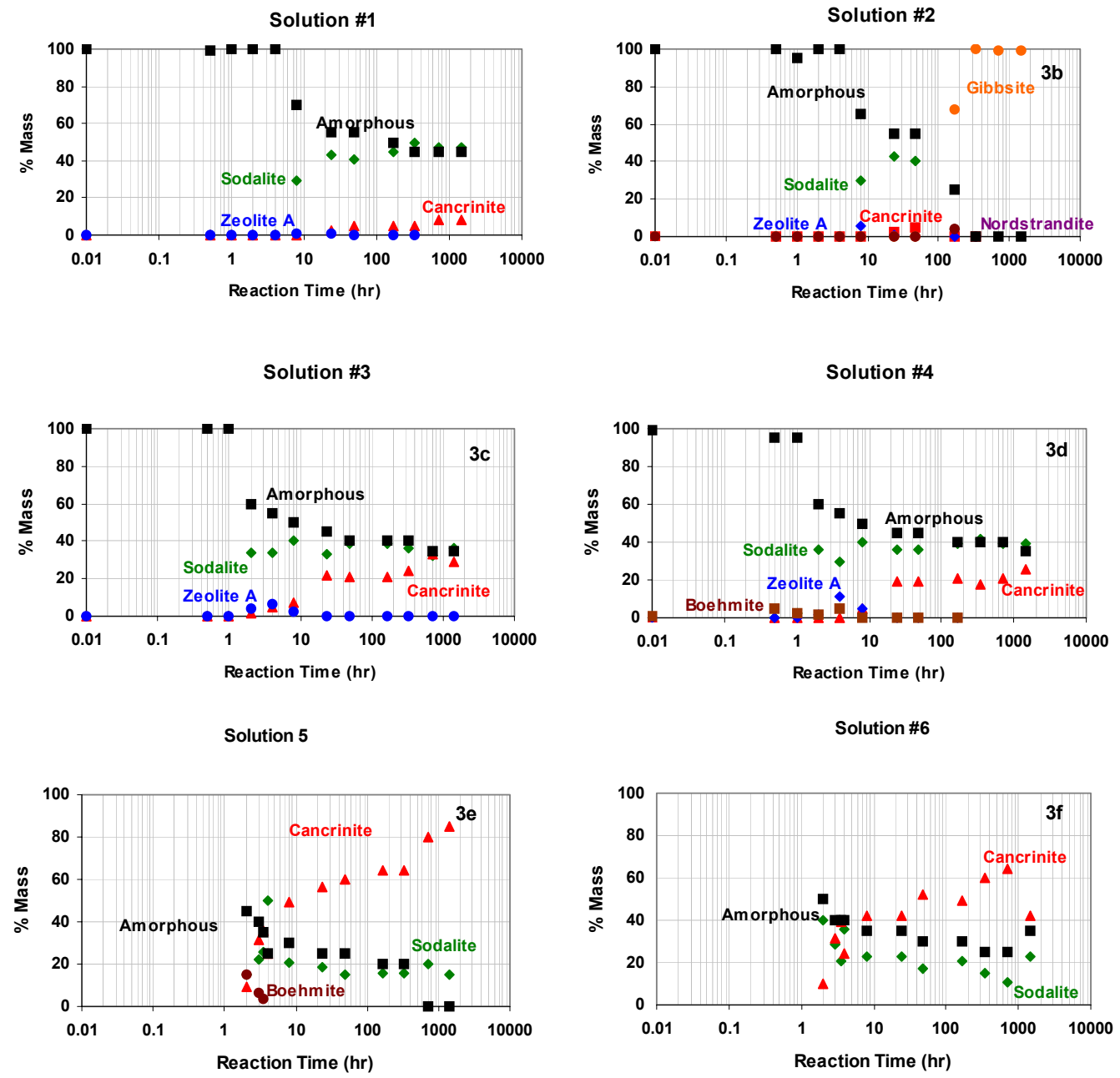

Figure 3. Solid Phases Identified as a Function of Reaction Time $\left(80^{\circ} \mathrm{C}\right)$ 
major fraction $(\sim 70 \%)$ of the solid mass with trace quantities of sodalite and nordstrandite. Reaction that continued for periods of 14, 30, and 60 days revealed no detectable quantities of amorphous material with gibbsite being the major crystalline phase with trace quantities of boehmite.

In Solution 3, during the initial reaction period extending up to 1 hour, only the amorphous phase was present (Figure 3c). However, at the end of 2 hours, sodalite constituted about a third of the solid mass with minor amounts of zeolite A and cancrinite. Additional samples obtained periodically from 1 to 60 days showed a continual decline in the quantity of amorphous material with increasing quantities of the crystalline fraction containing sodalite and cancrinite. Solid materials obtained after 30 and 60-day reaction times showed that the mass constituted roughly equal proportions of sodalite, cancrinite, and amorphous material.

The solid phases and their relative transformations with reaction progress in Solution 4 were substantially similar to what was observed in Solution 3, except that during the early phases of the reaction (up to 4 hours) traces of boehmite were detected in the predominantly amorphous matrix (Figure 3d).

The solids in Solution 5 during the initial stages of the reaction ( $<2$ hours) were mainly colloidal in nature and therefore could not be recovered in sufficient quantities for characterization.

Therefore, a larger volume of solution $(6 \mathrm{~L})$ was reacted for 2 hours to obtain sufficient quantities of precipitates for characterization. The precipitate consisted of an amorphous phase (about one-half the mass) and crystalline components such as sodalite, cancrinite, and boehmite (Figure 3e). In this sample, a trace amount of an unidentifiable crystalline component and some quartz were also present. With increasing reaction time, the quantities of amorphous material decreased while the mass of crystalline fraction increased. After 4 hours, about one-half of the solid mass consisted of sodalite, with the remaining mass consisting of cancrinite and amorphous material. As the reaction proceeded, the quantities of both sodalite and amorphous material decreased with a concomitant increase in the mass of cancrinite. Samples obtained at the end of the 60-day reaction period indicated that the solid mass consisted of only crystalline materials, cancrinite, and sodalite (Figure 3e).

Solids obtained at the end of 2 hours from Solution 6 (total volume $6 \mathrm{~L}$ ) also showed equal proportions of the amorphous phase with crystalline materials (mainly sodalite with minor amounts of cancrinite) (Figure 3f). Continued reaction generated increasing fractions of crystalline material that consisted of mainly cancrinite with decreasing amounts of sodalite. At the end of 60 days, about two-thirds of the material were crystalline in nature with cancrinite being the dominant crystalline phase.

The solid phases obtained from all solutions at the end of the 60-day reaction period are listed in Table 4. The data showed that except in Solution 2, rapid formation of sodalite and cancrinite occurred in all solutions. Although minor amounts of zeolite A were initially detected in some cases, the higher reaction temperatures seemed to promote very rapid transformation of this phase into more stable phases. Also, the higher temperature and hydroxide concentrations appeared to initiate kinetically fast crystallization of sodalite and cancrinite. 
Concentrations of dissolved species indicated that about $30-35 \%$ of $\mathrm{Al}$ in Solution 1 precipitated when the reaction was initiated (Figure 4a). As the reaction proceeded further, no additional $\mathrm{Al}$ appeared to precipitate. Initially, about $90-95 \%$ of dissolved Si precipitated, and complete precipitation occurred after about 24 hours of reaction time. Increased Si precipitation in this solution appeared to be associated with an increased rate of formation of sodalite.

In Solution 2, initially $\sim 20 \%$ of Al precipitated out of solution (Figure $4 \mathrm{~b}$ ). Additional Al precipitation occurred after about 4 hours and 24 hours. At the end of 60 days of reaction, about $55 \%$ of dissolved $\mathrm{Al}$ had precipitated. Precipitation of $\mathrm{Si}$ in this solution was similar with about $80 \%$ of the added Si precipitated initially, and after 4 hours of reaction, continued $\mathrm{Si}$ precipitation culminated in almost complete removal of $\mathrm{Si}$ from solution. Again, additional $\mathrm{Si}$ precipitation seemed to be triggered by the formation of sodalite. Also, precipitation of additional dissolved $\mathrm{Al}$ after about 48 hours of reaction coincided with the formation of gibbsite. Although the solution data indicated that crystalline aluminosilicates persisted at the end of the experiment, these phases were not detected by XRD because they constituted a minor fraction of

Table 4. Phases Identified at the End of 60-Day Reaction at $80^{\circ} \mathrm{C}$

\begin{tabular}{|c|c|c|c|c|c|}
\hline \multirow{2}{*}{$\begin{array}{l}\text { Solution } \\
\text { No. }\end{array}$} & \multicolumn{5}{|c|}{ Mass (wt \%) } \\
\hline & $100-80$ & $80-60$ & $60-40$ & $40-20$ & $20-<10$ \\
\hline 1 & & & $\begin{array}{l}\text { Sodalite, } \\
\text { Amorphous }\end{array}$ & & Cancrinite \\
\hline 2 & Gibbsite & & & & Boehmite \\
\hline 3 & & & & $\begin{array}{l}\text { Sodalite, } \\
\text { Cancrinite, } \\
\text { Amorphous }\end{array}$ & \\
\hline 4 & & & & $\begin{array}{l}\text { Sodalite, } \\
\text { Cancrinite, } \\
\text { Amorphous }\end{array}$ & \\
\hline 5 & Cancrinite & & & & Sodalite \\
\hline 6 & & & & $\begin{array}{l}\text { Cancrinite, } \\
\text { Sodalite, } \\
\text { Amornhous }\end{array}$ & \\
\hline $\begin{array}{l}\text { Sodalite: } \\
\text { Cancrini } \\
\text { Gibbsite: }\end{array}$ & $\begin{array}{l}\mathrm{Na}_{8}\left[\mathrm{AlSiO}_{4}\right] \\
\mathrm{Na}_{8}[\mathrm{AlSiC} \\
\mathrm{Al}(\mathrm{OH})_{3}(\mathrm{PI}\end{array}$ & $\begin{array}{l}\left.\mathrm{NO}_{3}\right)_{2}(\mathrm{PI} \\
6\left(\mathrm{NO}_{3}\right)_{2} \cdot 4 \\
{ }_{2} \\
33-001\end{array}$ & $\begin{array}{l}50-0248) \\
\text { O (PDF\#3 }\end{array}$ & 513) & \\
\hline
\end{tabular}

the solid mass that was dominated by gibbsite forming from additional $\mathrm{Al}$ precipitation that occurred after 48 hours.

The Al precipitation reactions in Solutions 3 and 4 seemed to follow similarly in that in both cases, initially about $20 \%$ of added $\mathrm{Al}$ precipitated (Figure $4 \mathrm{c}, \mathrm{d}$ ). After the reaction had progressed for about $4-8$ hours, an additional $\sim 10 \%$ of the $\mathrm{Al}$ was observed to precipitate. Precipitation of $\mathrm{Si}$ in both solutions was initially low $(\sim 5-10 \%)$, and additional precipitation seemed to occur after about half an hour and 2-hour reaction times. In both solutions, almost 
complete precipitation of Si had occurred after 24 hours of reaction. The solid phase characterization data (Figures 3c, d) suggested that the onset of additional Si removal in solution may be related to rapid formation of crystalline aluminosilicate phases such as sodalite and cancrinite.

Solution data indicated that initial reactions precipitated about $20-25 \%$ of Al in Solutions 5 and 6. Following this removal, no additional Al appeared to precipitate from either of these solutions during the remaining reaction period (Figure $4 \mathrm{e}, \mathrm{f}$ ). However, in both solutions, measurable precipitation of Si did not occur during the first 3.5 hours of reaction. Following this apparent quiescent period, extremely rapid removal of Si $(\sim 80-100 \%)$ was observed. Such rapid Si precipitation following the initially nonreactive stage appeared to be triggered by rapid crystal growth of aluminosilicate phases (sodalite and cancrinite) that may have initially formed from homogeneous nucleation.

These data suggested that removal of Si from solution was influenced strongly by hydroxide concentrations (Figure 4). Higher hydroxide concentrations appeared to delay the onset of
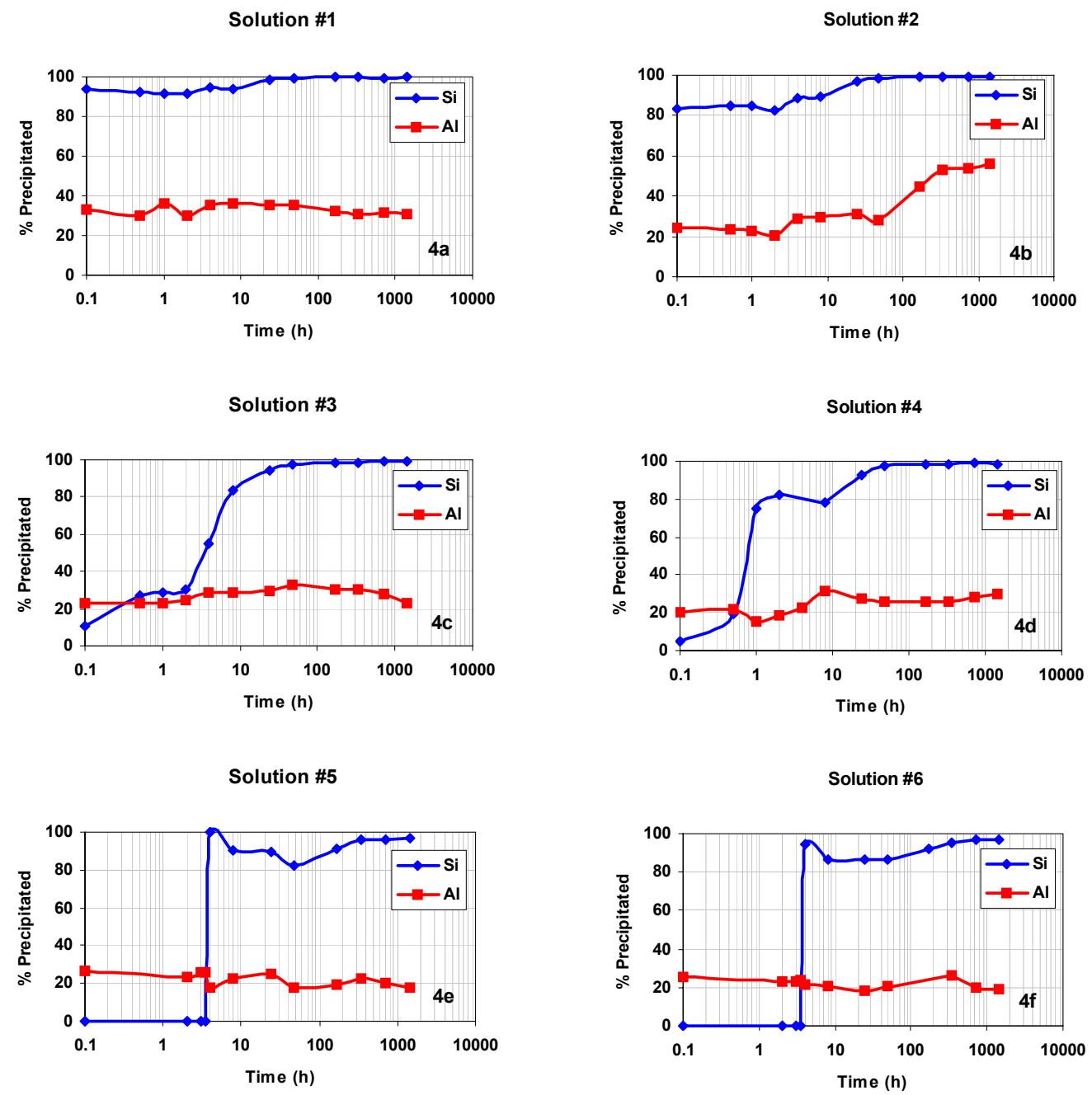

Figure 4. Fractions of $\mathrm{Al}$ and Si Precipitating Out of Solution $\left(80^{\circ} \mathrm{C}\right)$ 
formation of crystalline aluminosilicate phases. At present, the reason for the extended quiescent period (no Si precipitation) under high-hydroxide conditions is not known. However, Al and Si NMR measurements are expected to provide additional data to explain the kinetic hiatus.

\subsection{Turbidity and pH Measurements}

During the initial reaction period that extended for up to 8 hours, the $\mathrm{pH}$ of Solutions 1 and 2 declined steadily indicating that the precipitation reactions resulted in either release of protons or removal of hydroxyls from solution (Figure 5). The degree of change in $\mathrm{pH}$ appeared to depend

on the initial Al concentrations. Solution 2, containing a higher Al concentration, exhibited

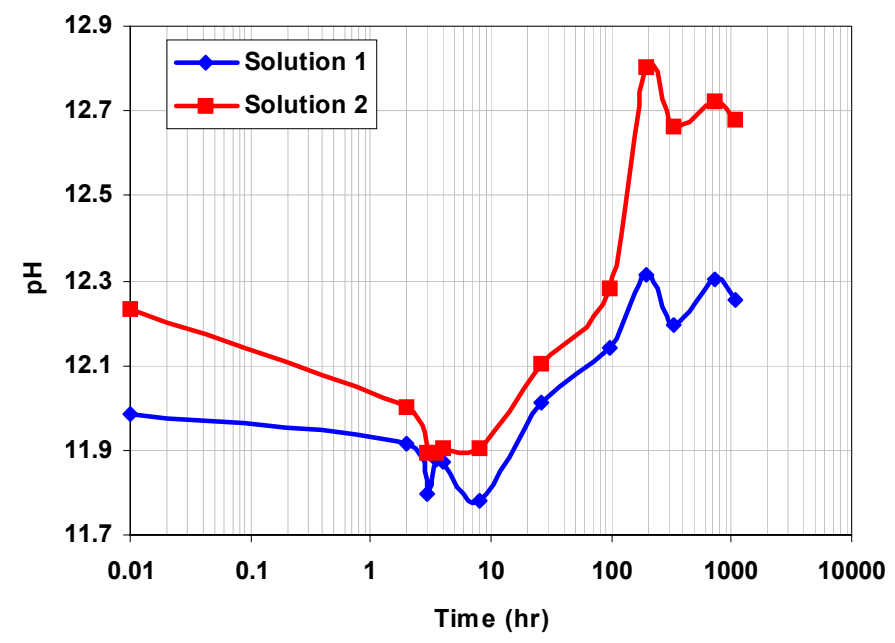

greater $\mathrm{pH}$ changes indicating that $\mathrm{Al}$ hydrolysis reactions may have engendered these observed changes in $\mathrm{pH}$. Observations beyond 8 hours showed that the $\mathrm{pH}$ of both solutions increased as a result of reactions that either removed protons or released hydroxyl. This phase of reaction coincided with the increasing formation of sodalite and cancrinite indicating the probable release of hydroxyls with continued conversion of amorphous material into crystalline phases.

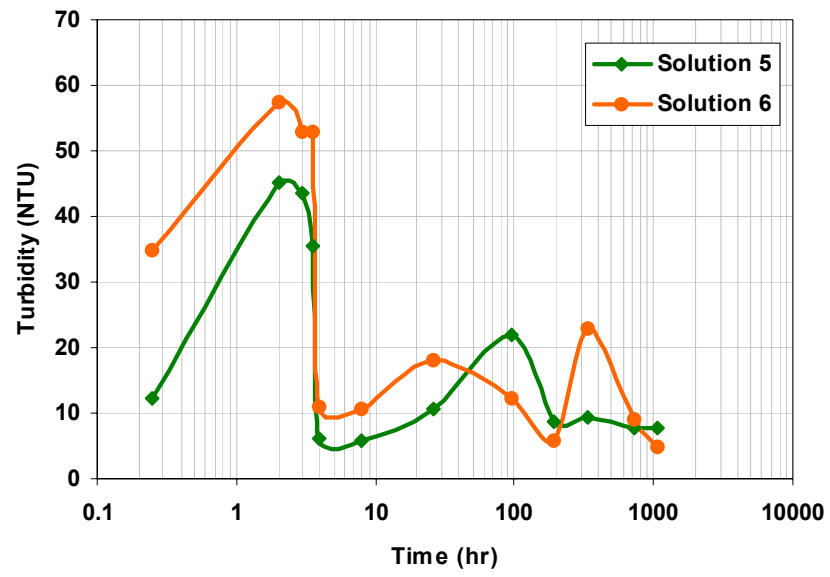




\section{Figure 6. Variation in Solution Turbidity as a Function of Reaction Time at $80^{\circ} \mathrm{C}$}

An increase in turbidity (Figure 6) of Solutions 5 and 6 during the initial phase of the reaction indicated the formation of colloids. At the end of 4 hours, there was a precipitous decline in turbidity indicating that colloid aggregation and precipitation had occurred. The formation of suspended colloids in these solutions precluded recovery of sufficient solid material for characterization.

\subsection{Comparison of Results with Previous Testing}

Previous testing, conducted primarily in support of the aluminum production industry, indicates sodium aluminosilicate phases form upon mixing alkaline solutions of aluminate and silicate. At temperatures below $80^{\circ} \mathrm{C}$, a number of studies reported formation of zeolite $\mathrm{A}^{18}$. With time, zeolite A transforms into sodalite ${ }^{19,20,21}$, and other studies indicate that sodalite is also a metastable phase and therefore will transform into cancrinite ${ }^{22,23,24}$. The rate of transformation is influenced by a number of factors including temperature and the presence of other components such as hydroxide and carbonate ions. Based on these studies, Barnes et al. ${ }^{16}$ proposed the following order of precipitation at temperatures of less than $160^{\circ} \mathrm{C}$.

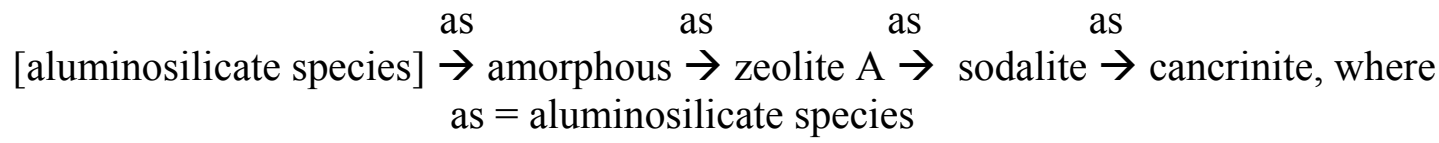

More recent testing in support of the HLW evaporator plugging issue has shown similar trends in the formation of aluminosilicate phases ${ }^{9,25,26}$. These tests were carried out under conditions more similar to those that occur in HLW tanks and evaporators.

Comparison of our results with those reported above show very similar trends. Initially, an amorphous phase precipitates followed by a zeolite phase followed by formation of sodalite and finally cancrinite. Our results also show the expected trend of an increased rate of transformation into denser aluminosilicate phases (sodalite and cancrinite) at higher temperature. Under high $\mathrm{Al}$ and low hydroxide concentrations, only gibbsite, $\mathrm{Al}(\mathrm{OH})_{3}$, is the identified crystalline material at equilibrium or near equilibrium conditions. Initially, a small amount of aluminosilicate solids precipitate. After depletion of the available silicon, gibbsite slowly crystallizes from solution and effectively dilutes the aluminosilicate phases to a concentration below that which can be detected by XRD.

\section{0 References}

\footnotetext{
${ }^{1}$ Wilmarth, W. R., C. J. Coleman, J. C. Hart, and W. T. Boyce. 2000. Characterization of Samples from the 242-16H Evaporator Wall. WSRC-TR-2000-00089, Westinghouse Savannah River Company, Aiken, South Carolina.
} 
${ }^{2}$ W. R. Wilmarth, S. D. Fink, D. T. Hobbs, and M. S. Hay. 1997. Characterization and Dissolution Studies of Samples from the 242-16H Evaporator Gravity Drain Line. WSRC-TR97-0326, Rev 0, Westinghouse Savannah River Company, Aiken, South Carolina.

${ }^{3}$ Wilmarth, W. R., C. J. Colemen, A. R. Jurgenson, W. M. Smith, J. C. Hart, W. T. Boyce, D. Missimer, and C. M. Conley. 2000. Characterization and Dissolution Studies of Samples from the 242-16H Evaporator. WSRC-TR-2000-00038, Rev 0, Westinghouse Savannah River Company, Aiken, South Carolina.

${ }^{4}$ Boley, C. S., M. C. Thompson, and W. R. Wilmarth. 2000 Technical Basis for the 242-16H Evaporator Cleaning Flowsheet. WSRC-TR-2000-00038, Rev 0, Westinghouse Savannah River Company, Aiken, South Carolina.

${ }^{5}$ Bowers, T. S., K. J. Jackson, and H. C. Helgeson. 1984. Equilibrium Activity Diagrams for Coexisting Minerals and Aqueous Solutions at Pressures and Temperatures to $5 \mathrm{~kb}$ and $600^{\circ} \mathrm{C}$. Springer,New York.

${ }^{6}$ Garrels, R. M., and C. L. Christ. 1965. Solutions, Minerals, and Equilibria. Harper and Row, New York.

${ }^{7}$ Ragnarsdottir, K. V. 1993. "Dissolution Kinetics of Heulandite at $\mathrm{pH} 2-12$ and $25^{\circ} \mathrm{C}$ ". Geochim. Cosmochim. Acta, 57, 2439-2449.

${ }^{8}$ Bowers, T. S., and R. G. Burns. 1990. "Activity Diagrams for Clioptilolite: Susceptibility of this Zeolite to Furthur Diagenetic Reactions," Am. Mineral. 75, 601-619.

${ }^{9}$ A. J. Mattus, C. H. Mattus and R. D. Hunt. 2001 Kinetic Testing of Nitrate-Based Sodalite Formation Over the Temperature Range of 40 to $100^{\circ} \mathrm{C}$, ORNL/TM-2001/117, Oak Ridge National Laboratory, Oak Ridge, Tennessee.

${ }^{10}$ Jantzen, C. M., and J. E. Laurinat. 2001. Thermodynamic Modeling of Deposition in Savannah River Site (SRS) Evaporators. WSRC-TR-2000-00293, Rev 0, Westinghouse Savannah River Company, Aiken, South Carolina.

${ }^{11}$ Barrer, R. M., J. W. Baynham, F. W. Bultitude, and W. M. Meier. 1959. "Hydrothermal Chemistry of Silicates. Part V Low-Temperature Crystal Growth of Aluminosilicates, and Some Gallium and Germanium Analogues." J. Chem. Soc. London. 195-208.

${ }^{12}$ Johnson, S. G., and W. L. Ebert. 2000. "Extension of C1285-97 to the ANL Ceramic Waste Form.” ASTM C26.13, American Society of Testing Materials, Philadelphia, Pennsylvania.

${ }^{13}$ Milton, R. M. 1959. U. S. Patents 2,882,243 and 2,882,244.

${ }^{14}$ Gasteiger, W. J. Frederick, and R. C. Streisel. 1992. "Solubility of Aluminosilicates in Alkaline Solutions and a Thermodynamic Equilibrium Model." Ind. Eng. Chem. Res. 31, 11831190 . 
${ }^{15}$ Ejaz, T., A. G. Jones, and P. Graham. 1999. "Solubility of Zeolite A and ots Amorphous Precursor under Synthetic Conditions." J. Chem. Eng. Data. 44:574-576.

${ }^{16}$ M. C. Barnes, J. Addai-Mensah and A. R. Gerson. 1999. "The Mechanism of the Sodalite-toCancrinite Phase Transformation in Synthetic Spent Bayer Liquor.” Micro. Meso. Mat. 31:287302.

${ }^{17}$ Jantzen, C. M. 1989. Vitrification of M-Area Mixed (Hazardous and Radioactive) Wastes: I. Sludge and Supernate Characterization" WSRC-TR-94-0234, Westinghouse Savannah River Company, Aiken, South Carolina.

${ }^{18}$ J. T. Wehrli and D. D. Aguila. 1993. "Preparation of DSP at Low Temperatures," 22.12, Queensland Alumina Ltd.

${ }^{19}$ B. Subotic, D. Skritic, I. Smit and L. Sekovanic, [need date and title] J. Cryst. Growth, 50(1980) 498.

${ }^{20}$ B. Subotic and L. Sekovanic, [need date and title] J. Cryst. Growth, 75(1986) 561.

${ }^{21}$ B. Grujic, B. Subotic, L. J. A. Despotovic, in P. A. Jacobs and R. A. Van Santen (eds). 1989. Studies in Surface Science and Catalysis No. 24, Zeolites - Synthesis, Structure, Technology and Application, Elsevier, Amsterdam, 261.

${ }^{22}$ J. Addai-Mensah, A. R. Gerson, K. Zheng, A. O’Dea, and R. St. C. Smart. 1997. [need title] Light Metals, 23.

${ }^{23}$ K. Zheng, J. Addai-Mensah, A. RT. Gerson, and R. St. C. Smart. 1998. [need title] J. Chem. And Eng. Data, 43(3)1998, 31.

${ }^{24}$ M. C. Barnes, J. Addai-Mensah, and A. R. Gerson. 1999. [need title] J. Cryst. Growth, 200(1999), 246.

${ }^{25}$ S. Rosencrance, D. Herman, and D. Healy. 2001. Formation and Deposition of Aluminosilicates in Support of the 2H-Evaporator Fouling Problem, WSRC-TR-2001-00464, Rev. 0, Westinghouse Savannah River Company, Aiken, South Carolina.

${ }^{26}$ M. Z. Hu, D. W. DePauli, and D. T. Bostick. 2001. "Dynamic Particle Growth Testing: Phase I Studies," ORNL/TM-2001/100, Oak Ridge National Laboratory, Oak Ridge, Tennessee. 
Appendix A 


\section{Semi Quantitative Method for Phase Determination from X-Ray Diffraction Data}

\section{Amorphous Content}

The amorphous material content was determined as a ratio of the integrated background to the total integrated intensity of each diffraction pattern. Both the integrated background and the total integrated intensity were corrected for the instrumental background (background due to the sample holder, etc.). Using this method, the amorphous content can be estimated with an accuracy of $\sim 10 \%$. The method of estimation is as follows:

1. Obtain the total integrated intensity for a diffraction pattern.

2. Fit a spline to the background of the diffraction pattern (background generated from Xray scattering from the amorphous component in the sample) to obtain the integrated background intensity.

3. Scan the same blank sample holder to obtain the instrumental background.

As an example, in Figure A.1, the total integrated intensity obtained from the diffraction pattern was 143,348 counts. Spline-fitting the background (red line) provided the integrated background intensity due to amorphous component as 74,358 counts. The instrumental background (green line) established for the specific diffractometer and the sample holder was 20,509 counts.

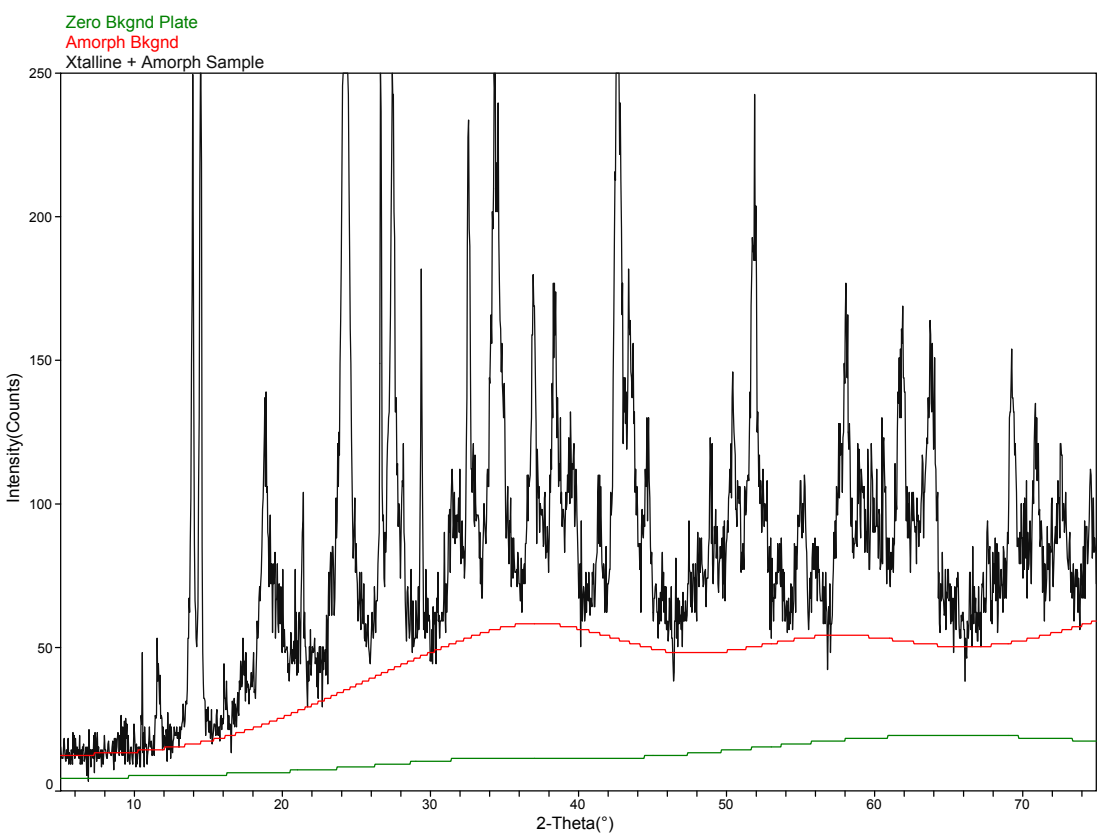

Figure A.1 X-Ray Scattering Components that Contribute to the Total Diffracted Intensity for a Sample Containing Both Amorphous and Crystalline Components

From these data, the amorphous content in the sample was calculated as $=($ Integrated background intensity - instrument background)/ (Total integrated intensity - instrument background $)=(74,358-20,509) /(143,348-20,509)=0.438$. Therefore, the amount of amorphous material in the sample was estimated to be $\sim 45 \%$ by weight. 
Source of Errors for Amorphous Content Estimation: One of the source of error stems from the method of differentiating the integrated background intensity from the total diffracted intensity. This background intensity due to the X-ray scattering from the amorphous component in a sample is partitioned from the total intensity by spline-fitting. Therefore, intensity partitioning is dependent on not only the accuracy of spline-fitting by an individual data analyst but also on the variations among other data analysts in spline-fitting the background intensity. Another source of error in amorphous content estimation is in accounting for fluorescence effects from $\mathrm{Fe}$ - and $\mathrm{Cu}-$ bearing materials. Typically, fluorescence from a sample increases the background intensity more or less linearly with increasing diffracting angle $(2 \theta)$. This source of error can be minimized if instrumental background is established from scanning a fully crystallized powder specimen of similar chemical composition. Because the samples we analyzed did not contain measurable concentrations of $\mathrm{Fe}$ and/or $\mathrm{Cu}$, the fluorescence effects were not a significant part of the background intensity.

\section{Crystalline Phase Content}

Semi-quantification of crystalline phase content was based on the ratio of the peak height above background for each identified phase to the combined peak heights of all phases present. Using $J A D E$ (Materials Data Inc., Livermore, California) software, this was accomplished by scaling PDF reference data against the background-subtracted experimental patterns. Normally, the $100 \%$ peak for each phase was used for scaling. Where this was not possible due to superposition, the strongest resolved peak was utilized. The sum of the phase scale factors was taken to be the total diffracted intensity, and the concentration of each phase was determined from the ratio of its scale factor to the sum.

It is important to note that this scaling process and calculation scheme are equivalent to what is often called "peak height analysis." Because this is a standardless method, the results from this type of analysis yield only semi-quantitative estimates. Because the crystalline phase content is determined separately from the amorphous phase content, the quantity of each crystalline phase in the whole sample was calculated by normalizing as follows:

$$
\mathrm{C}_{\mathrm{n}}=\mathrm{C}_{\mathrm{n}}^{\prime}(1-\mathrm{A} / 100)
$$

Where, $\mathrm{C}_{\mathrm{n}}=$ Content of $\mathrm{nth}$ crystalline phase in the sample matrix (\%)

$\mathrm{C}_{1}^{\prime}=$ Content of $\mathrm{nth}$ crystalline phase in the crystalline mass $(\%)$

$\mathrm{A}=$ Amorphous phase content in the sample (\%).

\section{Semiquantitative Estimation of Cancrinite and Sodalite}

A number of diffraction peaks of cancrinite and sodalite overlap. Therefore, for samples containing both cancrinite and sodalite, the method used for semiquantitative estimation was as follows. The concentration of cancrinite, was calculated using the scaled (211) peak. The sodalite concentration estimates were based on its scaled (310) peak. Both peaks are free from superposition with lines from the other phase i.e., cancrinite (211) peak is not overlapped by any sodalite diffraction peaks, and similarly, the sodalite (310) peak is not overlapped by any cancrinite diffraction peaks). 
Source of Errors for Crystalline Phase Content Estimation: The principal source of error in this standardless method of estimating crystalline component stems from the fact that the composition, particle size, and crystallite size of the PDF reference materials used in scaling do not duplicate the diffraction intensities of crystalline phases in the sample. Another source of error in the standardless approach is that the different crystalline materials and structures exhibit different X-ray scattering properties even if the scattering factors such as diffracting crystallite size and chemical composition of the phases are similar to one another or to the PDF reference data. Therefore, the accuracy of this method of estimation is no better than $10-15 \%$. 
Appendix B 
Table B.1. Solution Composition and Solid Phase Data from the $40{ }^{\circ} \mathrm{C}$ Experiments

\begin{tabular}{|c|c|c|c|c|c|c|c|c|c|}
\hline \multicolumn{10}{|c|}{ Solution \#1 } \\
\hline Time (hrs) & $\mathbf{S i}$ & Al & $\mathbf{N a}$ & OH & NO3 & $\begin{array}{l}\text { "Amorphous" } \\
\text { Pre-cursor }\end{array}$ & Sodalite & Cancrinite & Zeolite A \\
\hline & \multicolumn{5}{|c|}{ Solution (Molality) } & \multicolumn{4}{|c|}{ Solid (Mass \%) } \\
\hline Before Mixing & 0.0104 & 0.1712 & 3.81 & 0.12 & 3.45 & & & & \\
\hline 336 & 0.0005 & 0.1498 & & & & $\sim 80$ & & & $\sim 20$ \\
\hline 720 & 0.0002 & 0.1515 & & & & $\sim 35$ & & & $\sim 65$ \\
\hline 1080 & 0.0001 & 0.1537 & & & & $\sim 35$ & & & $\sim 65$ \\
\hline 1440 & 0.0001 & 0.1568 & & & & $\sim 35$ & & & $\sim 65$ \\
\hline \multicolumn{10}{|c|}{ Solution \#2 } \\
\hline Before Mixing & 0.0088 & 0.4241 & 4.18 & 0.12 & 3.47 & & & & \\
\hline 336 & 0.0011 & 0.4115 & & & & $\sim 40$ & & & $\sim 60$ \\
\hline 720 & 0.0003 & 0.4038 & & & & $\sim 40$ & & & $\sim 60$ \\
\hline 1080 & 0.0002 & 0.4110 & & & & $\sim 35$ & & & $\sim 65$ \\
\hline 1440 & 0.0002 & 0.4037 & & & & $\sim 35$ & & & $\sim 65$ \\
\hline \multicolumn{10}{|c|}{ Solution \#3 } \\
\hline Before Mixing & 0.0096 & 0.1623 & 4.91 & 1.17 & 3.50 & & & & \\
\hline 336 & $\mid 0.0010$ & 0.1632 & & & & $\sim 45$ & $\sim 10$ & $<10$ & $\sim 45$ \\
\hline 720 & 0.0005 & 0.1422 & & & & $\sim 45$ & $\sim 10$ & $<10$ & $\sim 40$ \\
\hline 1080 & 0.0005 & 0.1639 & & & & $\sim 45$ & $\sim 10$ & $<10$ & $\sim 40$ \\
\hline 1440 & 0.0006 & 0.1732 & & & & $\sim 45$ & $\sim 15$ & $\sim 10$ & $\sim 30$ \\
\hline \multicolumn{10}{|c|}{ Solution \#4 } \\
\hline Before Mixing & 0.0086 & 0.4376 & 5.24 & 1.16 & 3.48 & & & & \\
\hline 336 & 0.0017 & 0.4568 & & & & $\sim 45$ & $<10$ & & $\sim 50$ \\
\hline 720 & 0.0007 & 0.4259 & & & & $\sim 45$ & $<10$ & $<10$ & $\sim 50$ \\
\hline 1080 & 0.0006 & 0.4176 & & & & $\sim 45$ & $<10$ & $<10$ & $\sim 50$ \\
\hline 1440 & 0.0006 & 0.4492 & & & & $\sim 45$ & $<10$ & $<10$ & $\sim 50$ \\
\hline \multicolumn{10}{|c|}{ Solution \#5 } \\
\hline Before Mixing & 0.0115 & 0.1874 & 9.23 & 5.39 & 3.59 & & & & \\
\hline 336 & 0.0050 & 0.1841 & & & & $\sim 35$ & $\sim 25$ & $\sim 40$ & \\
\hline 720 & 0.0033 & 0.1753 & & & & $\sim 35$ & $\sim 20$ & $\sim 45$ & \\
\hline 1080 & 0.0025 & 0.1791 & & & & $\sim 35$ & $\sim 20$ & $\sim 45$ & \\
\hline 1440 & 0.0026 & 0.1934 & & & & $\sim 35$ & $\sim 20$ & $\sim 45$ & \\
\hline \multicolumn{10}{|c|}{ Solution \#6 } \\
\hline Before Mixing & 0.0121 & 0.4987 & 9.83 & 5.52 & 3.68 & & & & \\
\hline 336 & 0.0015 & 0.4695 & & & & $\sim 45$ & $\sim 25$ & $\sim 30$ & \\
\hline 720 & 0.0023 & 0.4712 & & & & $\sim 45$ & $\sim 25$ & $\sim 30$ & \\
\hline 1080 & 0.0022 & 0.4873 & & & & $\sim 40$ & $\sim 20$ & $\sim 40$ & \\
\hline 1440 & 0.0017 & 0.5118 & & & & $\sim 40$ & $\sim 20$ & $\sim 40$ & \\
\hline
\end{tabular}


Table B.2. Solution Composition and Solid Phase Data from the $80{ }^{\circ} \mathrm{C}$ Experiments

\begin{tabular}{|c|c|c|c|c|c|c|c|c|c|c|c|c|c|c|c|}
\hline \multicolumn{16}{|c|}{ Solution \#1 } \\
\hline \multirow[t]{2}{*}{ Time (hrs) } & pH & $\mathbf{S i}$ & Al & $\mathbf{N a}$ & OH & NO3 & $\begin{array}{l}\text { "Amor } \\
\text { " Pre- } \\
\text { cursor }\end{array}$ & Sodalite & Cancrinite & Zeolite A & Gibbsite & $\begin{array}{c}\text { Nord- } \\
\text { strandite }\end{array}$ & Boehmite & Quartz & $\begin{array}{c}\text { Un- } \\
\text { identified }\end{array}$ \\
\hline & & \multicolumn{5}{|c|}{ Solution (Molality) } & \multicolumn{9}{|c|}{ Solid (Mass \%) } \\
\hline \multicolumn{2}{|c|}{ Before Mixing } & 0.01149 & 0.2298 & 3.81 & 0.12 & 3.45 & & & & & & & & & \\
\hline 0.1 & 11.98 & 0.00067 & 0.1533 & & & & $\sim 100$ & & & & & & & & \\
\hline 0.5 & & 0.00093 & 0.1616 & & & & $\sim 100$ & & & & & & $<10$ & & \\
\hline 1 & & 0.00093 & 0.1462 & & & & $\sim 100$ & & & & & & & & \\
\hline 2 & 11.92 & 0.00094 & 0.1611 & & & & $\sim 100$ & & & & & & & & \\
\hline 4 & 11.87 & 0.00063 & 0.1493 & & & & $\sim 100$ & & & & & & & & \\
\hline 8 & 11.78 & 0.00067 & 0.1474 & & & & $\sim 70$ & $\sim 30$ & & $<10$ & & & & & \\
\hline 24 & 12.01 & 0.00021 & 0.1488 & & & & $\sim 55$ & $\sim 40$ & $<10$ & & & & & & \\
\hline 48 & & 0.00011 & 0.1487 & & & & $\sim 55$ & $\sim 40$ & $<10$ & & & & & & \\
\hline 168 & & 0.00004 & 0.1555 & & & & $\sim 50$ & $\sim 45$ & $<10$ & & & & & & \\
\hline 336 & 12.20 & 0.00004 & 0.1588 & & & & $\sim 45$ & $\sim 50$ & $<10$ & & & & & & \\
\hline 720 & 12.30 & 0.00007 & 0.1573 & & & & $\sim 45$ & $\sim 50$ & $<10$ & & & & & & \\
\hline 1440 & & 0.00004 & 0.1594 & & & & $\sim 45$ & $\sim 50$ & $<10$ & & & & & & \\
\hline \multicolumn{16}{|c|}{ Solution \#2 } \\
\hline Before Mixin & & 0.01157 & 0.5786 & 4.18 & 0.12 & 3.47 & & & & & & & & & \\
\hline 0.1 & 12.23 & 0.00193 & 0.4388 & & & & $\sim 100$ & & & & & & & & \\
\hline 0.5 & & 0.00175 & 0.4419 & & & & $\sim 100$ & & & & & & & & \\
\hline 1 & & 0.00176 & 0.4452 & & & & $\sim 95$ & & & & & & $<10$ & & \\
\hline 2 & 12.00 & 0.00197 & 0.4599 & & & & $\sim 100$ & & & & & & & & \\
\hline 4 & 11.90 & 0.00129 & 0.4099 & & & & $\sim 100$ & & & & & & & & \\
\hline 8 & 11.91 & 0.00125 & 0.4069 & & & & $\sim 65$ & $\sim 30$ & & $<10$ & & & & & \\
\hline 24 & 12.10 & 0.00035 & 0.4004 & & & & $\sim 55$ & $\sim 40$ & $<10$ & & & & & & \\
\hline 48 & & 0.00018 & 0.4176 & & & & $\sim 55$ & $\sim 40$ & $<10$ & & & & & & \\
\hline 168 & & 0.00007 & 0.3212 & & & & $\sim 25$ & $<10$ & & & $\sim 70$ & $<10$ & & & \\
\hline 336 & 12.66 & 0.00006 & 0.2711 & & & & & & & & $\sim 100$ & $<10$ & & & \\
\hline 720 & 12.70 & 0.00007 & 0.2681 & & & & & & & & $\sim 100$ & & $<10$ & & \\
\hline 1440 & & 0.00006 & 0.2527 & & & & & & & & $\sim 100$ & & $<10$ & & \\
\hline
\end{tabular}




\begin{tabular}{|c|c|c|c|c|c|c|c|c|c|c|c|c|c|c|}
\hline \multicolumn{15}{|c|}{ Solution \#3 } \\
\hline Time (hrs) & $\mathbf{S i}$ & Al & $\mathbf{N a}$ & OH & NO3 & $\begin{array}{l}\text { "Amor } \\
\text { " Pre- } \\
\text { cursor }\end{array}$ & Sodalite & Cancrinite & Zeolite A & Gibbsite & $\begin{array}{c}\text { Nord- } \\
\text { strandite }\end{array}$ & Boehmite & Quartz & $\begin{array}{c}\text { Unidentif } \\
\text { ied }\end{array}$ \\
\hline & \multicolumn{5}{|c|}{ Solution (Molality) } & \multicolumn{9}{|c|}{ Solid (Mass \%) } \\
\hline Before Mixing & 0.01165 & 0.2331 & 4.91 & 1.17 & 3.50 & & & & & & & & & \\
\hline 0.1 & 0.01043 & 0.1793 & & & & $\sim 100$ & & & & & & & & \\
\hline 0.5 & 0.00852 & 0.1799 & & & & $\sim 100$ & & & & & & & & \\
\hline 1 & 0.00828 & 0.1795 & & & & $\sim 100$ & & & & & & & & \\
\hline 2 & 0.00813 & 0.1754 & & & & $\sim 60$ & $\sim 35$ & $<10$ & $<10$ & & & & & \\
\hline 4 & 0.00527 & 0.1662 & & & & $\sim 55$ & $\sim 35$ & $<10$ & $<10$ & & & & & \\
\hline 8 & \begin{tabular}{|l|}
0.00187 \\
\end{tabular} & 0.1665 & & & & $\sim 50$ & $\sim 40$ & $\sim 10$ & $<10$ & & & & & \\
\hline 24 & 0.00068 & 0.1640 & & & & $\sim 45$ & $\sim 30$ & $\sim 20$ & & & & & & \\
\hline 48 & 0.00032 & 0.1574 & & & & $\sim 40$ & $\sim 40$ & $\sim 20$ & & & & & & \\
\hline 168 & 0.00017 & 0.1618 & & & & $\sim 40$ & $\sim 40$ & $\sim 20$ & & & & & & \\
\hline 336 & 0.00022 & 0.1616 & & & & $\sim 40$ & $\sim 40$ & $\sim 20$ & & & & & & \\
\hline 720 & 0.00011 & 0.1683 & & & & $\sim 35$ & $\sim 30$ & $\sim 35$ & & & & & & \\
\hline 1440 & 0.00012 & 0.1786 & & & & $\sim 35$ & $\sim 35$ & $\sim 30$ & & & & & & \\
\hline \multicolumn{15}{|c|}{ Solution \#4 } \\
\hline Before Mixing & 0.01161 & 0.5806 & 5.24 & 1.16 & 3.48 & & & & & & & & & \\
\hline 0.1 & 0.01110 & 0.4648 & & & & $\sim 100$ & & & & & & $<10$ & & \\
\hline 0.5 & 0.00939 & 0.4531 & & & & $\sim 95$ & & & & & & $<10$ & & \\
\hline 1 & 0.00290 & 0.4908 & & & & $\sim 95$ & $<10$ & & & & & $<10$ & & \\
\hline 2 & 0.00207 & 0.4748 & & & & $\sim 60$ & $\sim 35$ & & $<10$ & & & $<10$ & & \\
\hline 4 & & 0.4512 & & & & $\sim 55$ & $\sim 30$ & & $\sim 10$ & & & $<10$ & & \\
\hline 8 & 0.00249 & 0.3993 & & & & $\sim 50$ & $\sim 40$ & $<10$ & $<10$ & & & & & \\
\hline 24 & 0.00084 & 0.4206 & & & & $\sim 45$ & $\sim 35$ & $\sim 20$ & & & & & & \\
\hline 48 & 0.00032 & 0.4324 & & & & $\sim 45$ & $\sim 35$ & $\sim 20$ & & & & & & \\
\hline 168 & 0.00019 & 0.4305 & & & & $\sim 40$ & $\sim 40$ & $\sim 20$ & & & & & & \\
\hline 336 & 0.00017 & 0.4303 & & & & $\sim 40$ & $\sim 40$ & $\sim 20$ & & & & & & \\
\hline 720 & 0.00014 & 0.4165 & & & & $\sim 40$ & $\sim 40$ & $\sim 20$ & & & & & & \\
\hline 1440 & 0.00014 & 0.4093 & & & & $\sim 35$ & $\sim 40$ & $\sim 25$ & & & & & & \\
\hline & & & & & & & & & & & & & & \\
\hline
\end{tabular}




\begin{tabular}{|c|c|c|c|c|c|c|c|c|c|c|c|c|c|c|}
\hline \multicolumn{15}{|c|}{ Solution \#5 } \\
\hline Time (hrs) & $\mathbf{S i}$ & $\mathbf{A l}$ & $\mathbf{N a}$ & $\mathbf{O H}$ & NO3 & $\begin{array}{l}\text { "Amor } \\
\text { " Pre- } \\
\text { cursor }\end{array}$ & Sodalite & Cancrinite & Zeolite A & Gibbsite & $\begin{array}{l}\text { Nord- } \\
\text { strandite }\end{array}$ & Boehmite & Quartz & $\begin{array}{l}\text { Un- } \\
\text { identified }\end{array}$ \\
\hline & \multicolumn{5}{|c|}{ Solution (Molality) } & \multicolumn{9}{|c|}{ Solid (Mass \%) } \\
\hline Before Mixing & 0.01197 & 0.2394 & 9.23 & 5.39 & 3.59 & & & & & & & & & \\
\hline 0.1 & 0.01360 & 0.1762 & & & & & & & & & & & & \\
\hline 2 & 0.01371 & 0.1830 & & & & $\sim 45$ & $\sim 15$ & $\sim 10$ & & & & $\sim 15$ & $\sim 10$ & $<10$ \\
\hline 3 & 0.01280 & 0.1775 & & & & $\sim 40$ & $\sim 20$ & $\sim 30$ & & & & $<10$ & & \\
\hline 3.5 & 0.01331 & 0.1776 & & & & $\sim 35$ & $\sim 25$ & $\sim 35$ & & & & $<10$ & & \\
\hline 4 & & 0.1960 & & & & $\sim 25$ & $\sim 50$ & $\sim 25$ & & & & & & \\
\hline 8 & 0.00111 & 0.1848 & & & & $\sim 30$ & $\sim 20$ & $\sim 50$ & & & & & & \\
\hline 24 & 0.00127 & 0.1801 & & & & $\sim 25$ & $\sim 20$ & $\sim 55$ & & & & & & \\
\hline 48 & 0.00210 & 0.1965 & & & & $\sim 25$ & $\sim 15$ & $\sim 60$ & & & & & & \\
\hline 168 & 0.00111 & 0.1939 & & & & $\sim 20$ & $\sim 15$ & $\sim 65$ & & & & & & \\
\hline 336 & 0.00046 & 0.1845 & & & & $\sim 20$ & $\sim 15$ & $\sim 65$ & & & & & & \\
\hline 720 & 0.00044 & 0.1914 & & & & & $\sim 20$ & $\sim 80$ & & & & & & \\
\hline 1440 & 0.00041 & 0.1973 & & & & & $\sim 15$ & $\sim 85$ & & & & & & \\
\hline \multicolumn{15}{|c|}{ Solution \#6 } \\
\hline Before Mixing & 0.01227 & 0.6133 & 9.83 & 5.52 & 3.68 & & & & & & & & & \\
\hline 0.1 & 0.01019 & 0.4568 & & & & & & & & & & & & \\
\hline 2 & 0.01385 & 0.4730 & & & & $\sim 50$ & $\sim 40$ & $<10$ & & & & & & \\
\hline 3 & 0.01388 & 0.4725 & & & & $\sim 40$ & $\sim 30$ & $\sim 30$ & & & & & & \\
\hline 3.5 & 0.01267 & 0.4673 & & & & $\sim 40$ & $\sim 20$ & $\sim 40$ & & & & & & \\
\hline 4 & 0.00064 & 0.4840 & & & & $\sim 40$ & $\sim 35$ & $\sim 25$ & & & & & & \\
\hline 8 & 0.00165 & 0.4864 & & & & $\sim 35$ & $\sim 25$ & $\sim 40$ & & & & & & \\
\hline 24 & 0.00165 & 0.5017 & & & & $\sim 35$ & $\sim 25$ & $\sim 40$ & & & & & & \\
\hline 48 & 0.00167 & 0.4879 & & & & $\sim 30$ & $\sim 20$ & $\sim 50$ & & & & & & \\
\hline 168 & 0.00096 & & & & & $\sim 30$ & $\sim 20$ & $\sim 50$ & & & & & & \\
\hline 336 & 0.00061 & 0.4526 & & & & $\sim 25$ & $\sim 15$ & $\sim 60$ & & & & & & \\
\hline 720 & 0.00035 & 0.4925 & & & & $\sim 25$ & $\sim 10$ & $\sim 65$ & & & & & & \\
\hline 1440 & 0.00040 & 0.4966 & & & & $\sim 35$ & $\sim 25$ & $\sim 40$ & & & & & & \\
\hline
\end{tabular}



Author

S. V. Mattigod Date

Pacific Northwest National Laboratory

Date

D. T. Hobbs

Waste Processing Technology

QA

PNNL Quality Section

Date

Management

W. B. Van Pelt

Date

Waste Processing Technology

B. L. Lewis, Manager

Date

CST Engineering

W. L. Tamosaitis, Manager

Date

Waste Processing Technology

PNNL Manager 


\section{Distribution}

No. of

Copies

OFFSITE

3 Oak Ridge National Laboratory

P.O. Box 2008

Oak Ridge, TN 37831

C.Weber

C.P McGinnis

R. Hunt

No. of

Copies

ONSITE

2 Pacific Northwest National Laboratory

S.V. Mattigod K6-81

K.E. Parker P8-37

D.E.McCready K8-93

L. Q. Wang K2-44

Information Release Office (7) K1-06

\section{Savannah River Site}

D. T. Hobbs

Westinghouse Savannah River Company

SRTC Bldg773-A, Rm B-117

Aiken, SC 29808 